This document is the accepted manuscript version of the following article:

Busetti, F., Ruff, M., \& Linge, K. L. (2015). Target screening of chemicals of

concern in recycled water. Environmental Science: Water Research and Technology, 1 ,

659-667. https://doi.org/10.1039/C4EW00104D

\title{
Target Screening of Chemicals of Concern in Recycled Water
}

F. Busetti ${ }^{a, *}, M$. Ruff $^{\mathrm{b}}$ and K.L. Linge ${ }^{\mathrm{a}}$

${ }^{a}$ Curtin Water Quality Research Centre, Department of Chemistry, Curtin University, GPO Box U1987, Perth, Western Australia 6845, Australia

${ }^{b}$ Eawag, Swiss Federal Institute of Aquatic Science and Technology, Ueberlandstrasse 133, 8600 Dubendorf, Switzerland

*Corresponding author: Curtin Water Quality Research Centre, Department of Chemistry, Curtin University, GPO Box U1987, Perth, Western Australia 6845, Australia. Tel.: +61 89266 3273; fax: +61 89266 2300. E-mail address: f.busetti@curtin.edu.au (F. Busetti).

Keywords: water reuse, wastewater, reverse osmosis, PPCPs, pesticides, biocides, target screening, risk quotient 


\section{Abstract}

The results of a characterisation study of water samples collected from an Advanced Water Recycling Plant (AWRP) operating in Perth, Western Australia are presented. The AWRP treats secondary wastewater by ultrafiltration, reverse osmosis (RO) and ultraviolet radiation (UV) to produce recycled water for groundwater replenishment. Water samples collected after RO and UV treatment were characterised by liquid chromatography-high resolution mass spectrometry, using an established protocol for target screening. The target screening of 291 compounds detected a total of 13 chemicals in post-RO and post-UV water, including 2 corrosion inhibitors $(4+5$ Methyl-1H-benzotriazole, benzotriazole), 3 pesticides (metolachlor, propiconazol, prosulfocarb), 3 pharmaceuticals (lamotrigin, metformin, tramadol), 1 personal care product (galaxalidone), 3 artificial sweeteners (saccharin, acesulfame, sucralose) and 1 flame retardant (triethyl phosphate). The corrosion inhibitors benzotriazole and 4+5-Methyl-1H-benzotriazole, and the pharmaceutical metformin were detected in hundreds of $\mathrm{ng} / \mathrm{L}$, while concentrations of the other compounds were present in low $\mathrm{ng} / \mathrm{L}$ concentrations. Analysis of UV treated water samples showed that UV treatment also helped to reduced UV degradable compounds such as the corrosion inhibitors ( $>50 \%$ removal), triethyl phosphate $(\sim 50 \%$ removal) and the artificial sweetener acesulfame ( $95 \%$ removal). Overall, the detection of 13 chemicals through target screening analyses did not account for the residual dissolved organic carbon (DOC) in post RO water, the majority of which is still an intriguing unknown. However, the target screening did show that there were no obvious "known" anthropogenic contaminants contributing to the majority of the DOC in post-RO and post-UV treated water. Calculated risk quotients $(R Q)$ for all detected chemicals in UV treated water were 2 to 6 order of magnitude below 1 , implying an high degree of safety associated with human consumption of recycled water. Overall the chemicals screening provided further evidence of the overall safety of the use of recycled wastewater treated by RO and UV as a potable water source. 


\section{Water Impact}

While research into the chemical safety of recycled water has focussed on measuring chemicals in recycled water, it is not clear what percentage of residual dissolved organic carbon (DOC) in recycled water results from anthropogenic chemicals. Here we show that anthropogenic chemicals do not contribute significantly to residual DOC in recycled water after RO and UV treatment. A risk assessment of the chemicals detected in the recycled water also demonstrates the high degree of safety associated with human consumption of recycled water. However, the study also highlights that end-product compliance testing for all potential chemicals is time consuming and expensive. Further research into the use of bioassays as a monitoring tool for water recycling is recommended.

\section{Introduction}

In recent years, Western Australia has experienced a significant reduction in rainwater precipitation levels which has corresponded to a reduction in water available from dams and groundwater for drinking water production. ${ }^{1}$ Use of treated wastewater as a drinking water source is becoming increasingly attractive, both in Australia and worldwide, and demonstrating that specific treatment technologies produce safe drinking water is of high importance, particularly focussing on chemical removal using reverse osmosis (RO) followed by ultraviolet irradiation (UV) for disinfection. Research into the safety of recycled water has focussed on monitoring and characterising residual concentrations of inorganic and organic micropollutants in the finished water. $^{2-4}$ Chemicals in wastewaters that potentially pose health concern include heavy metals, organic compounds with suspected carcinogenic properties (e.g. N-nitrosamines and halogenated disinfection by-products), pharmaceuticals and personal care products (e.g. endocrine disrupting compounds, cytostatics and antibiotics), pesticides and their degradation products, and other unregulated trace organic compounds (i.e. plasticisers, surfactants, musk fragrances, artificial sweeteners) derived from both domestic and industrial activities. $^{4,5}$ Therefore residual dissolved organic carbon (DOC) present in ROtreated wastewater may consist of anthropogenic organic compounds, in addition to residual organic matter originally present in drinking water and wastewater, or 
chemicals used during RO treatment or leached from RO membranes. ${ }^{6,7}$ Very few attempts to characterise this residual DOC have been reported to date, ${ }^{8,9}$ although a recent assessment of 375 chemicals in recycled water suggested that only $\sim 2-5 \%$ of DOC in the RO treated water could be attributed to regularly detected $(>25 \%$ detection) anthropogenic chemicals. ${ }^{10}$ In this work we present the results of a characterisation study of recycled water collected from an Advanced Water Recycling Plant (AWRP) located in Perth (WA) after both RO and UV treatment over four days. The water samples were extracted using mixed bed solid-phase extraction cartridges and then characterised by liquid chromatography-high resolution mass spectrometry.

While almost 400 chemicals were screened previously in RO treated wastewater from a Perth wastewater treatment plant, ${ }^{5}$ particular emphasis in this work was given to polar chemicals amendable by LC-MS. The target screening in this study assessed the occurrence of 291 chemicals including pharmaceuticals (88 compounds), pharmaceutical-metabolites (27 compounds), illicit drugs and metabolites (14 compounds), pesticides (79 compounds), pesticide-metabolites (51 compounds), biocides and metabolites (11 compounds), artificial sweeteners (6 compounds), personal care products (3 compounds), corrosion inhibitor and metabolites ( 5 compounds), industrial chemicals ( 5 compounds) and miscellaneous (2 compounds). Chemicals were selected based on 1) prior knowledge of their occurrence in wastewater inflow and outflow; 2) existing studies of recycled water and surface waters from previous surveys and literature.4,5,10,11 A snapshot of the chemicals and their transformation products and metabolites assessed in the target screening analysis is given in Figure 1 and the full list of the chemicals is reported in Table S1 available in the Supporting Information. Eighty five percent (248 of 291) of the target compounds were analysed in the Perth AWRP for the first time in this study. The contribution of detected chemicals to the residual dissolved organic carbon (DOC) measured in UV treated water was also assessed. For a screening health risk assessment, risk quotients $(R Q)$ were calculated by comparing median and maximum concentrations of chemicals measured in UV treated water with the corresponding health values. 


\section{Experimental}

\subsection{Sampling}

Samples were collected on four days (16/01/12 to 19/01/12), from an AWRP in Perth, Western Australia. Details of the AWRP have been previously published, ${ }^{11-13}$ but briefly, the AWRP receives secondary wastewater (WW) from Beenyup WWTP and produces high purity recycled water that is then injected into a deep drinking water aquifer. Beenyup WWTP receives predominantly urban residential wastewater, and the raw WW is screened to remove large material, before grit removal and primary sedimentation. The primary treated WW then undergoes conventional activated sludge treatment with biological nutrient removal before clarification. Most secondary WW from Beenyup WWTP is discharged into the Indian Ocean, while a small portion ( $7 \mathrm{ML} / \mathrm{d}$ ) is fed into the AWRP. Treatment at the AWRP consists of chloramination to minimise biofouling on membranes, ultrafiltration, reverse osmosis, and UV disinfection. A caustic dosing between the UV reactors is also present to adjust the $\mathrm{pH}$ to neutral conditions before the product water is degassed, stored and reinjected into the groundwater. After UF/RO/UV treatment, about $4.5 \mathrm{ML} / \mathrm{d}$ are reinjected into the groundwater aquifer, while the $R O$ reject (about $2.5 \mathrm{ML} / \mathrm{d}$ ) is sent back to the head of the WWTP. A schematic of the treatment train at Beenyup WWTP-AWRP including sampling points is shown in Figure 2.

Grab samples were collected directly after RO and UV treatment (i.e. after caustic dosing, see Figure 2) in $2 \mathrm{~L}$ amber glass bottles, previously annealed at $550{ }^{\circ} \mathrm{C}$ overnight to ensure thermal degradation of and residual organic material. Bottles were also rinsed with the sample prior to sample collection. Sample were chilled with ice packs during transport to the CWQRC laboratory, and then stored at $4{ }^{\circ} \mathrm{C}$ until extraction. Prior to processing though solid-phase extraction (SPE), all samples were re-equilibrated to room temperature and then filtered through $0.45 \mu \mathrm{m}$ Microfiberglass Duo-Fine ${ }^{\circ}$ Filter cartridges (PALL Life Sciences, East Hills, USA) pre-conditioned with $10 \mathrm{~L}$ of ultrapure water. To avoid cross contamination, a single filter cartridge was dedicated to each type of water processed. Quality control samples consisted of post RO water and laboratory ultrapure water, fortified with different concentrations of standards and surrogate standards. Laboratory blanks were also processed along with the batch of samples and analysed for quality control purpose. 


\subsection{Sample extraction}

Because of the low concentrations expected in the post RO and post UV water samples, solid-phase extraction (SPE) as described by Kern et al. ${ }^{14}$ was used to concentrate the analytes from the samples. Briefly, the $\mathrm{pH}$ of each sample $(2 \mathrm{~L})$ was adjusted to $6.5-6.7$ by adding $1 \mathrm{~mL}$ of ammonium acetate buffer $(1 \mathrm{~mol} / \mathrm{L})$ and formic acid or ammonia solutions as required. For accurate quantification using LC-MS analysis, $100 \mathrm{ng}$ of a surrogate standard mix containing 113 isotopically labelled substances were spiked to each sample. The layered 'mixed bed' cartridges for SPE consisted of $200 \mathrm{mg}$ of OASIS HLB material (30 micro-M; Waters AG, USA) and mixed phase (350 mg in all: $100 \mathrm{mg}$ Strata-X-AW (Phenomenex, USA), $100 \mathrm{mg}$ Strata-X-CW (Phenomenex, USA), $150 \mathrm{mg}$ Isolute ENV+ (Separtis $\mathrm{GmbH}$, Germany). An automated Aspec XLi extractor (Gilson, USA) was used for conditioning and elution of the cartridges. For conditioning, $5 \mathrm{~mL}$ of methanol and $10 \mathrm{~mL}$ of ultrapure water were dispensed at $2 \mathrm{~mL} / \mathrm{min}$. After conditioning, samples were loaded onto the SPE cartridges using two 8-channel off-line peristaltic pumps (Gilson) at a flow rate of $5 \mathrm{~mL} / \mathrm{min}$. Prior to elution, cartridges were completely dried using a vacuum manifold. The elution of the analytes from the SPE stationary phase was achieved by applying a basic solution ( $8 \mathrm{~mL}$ of ethylacetate/methanol containing $0.5 \%$ ammonia hydroxide $(\mathrm{v} / \mathrm{v})$ ), followed by an acidic solution $(4 \mathrm{~mL}$ of ethylacetate/methanol containing $1.7 \%$ formic acid $(\mathrm{v} / \mathrm{v})$ ) dispensed at $2 \mathrm{~mL} / \mathrm{min}$. The eluates were concentrated to about $100 \mu \mathrm{L}$ using a dry block heater $\left(30^{\circ} \mathrm{C}\right)$ fitted with nitrogen blowdown (Ratek 30D, Australia), before being rediluted to $1 \mathrm{~mL}$ using ultra pure water. Finally, the extracts were filtered directly into a $2 \mathrm{~mL}$ brown glass vial using a syringe fitted with a $0.45 \mu \mathrm{m}$ regenerated cellulose membrane filter (Infochroma AG, Switzerland). Samples extracts chilled with ice packs were shipped using an international express delivery service to EAWAG laboratories in Dübendorf (Switzerland) for analysis.

\subsection{Chromatographic separation}

For the reversed phase chromatographic separation, an aliquot of the extract $(20 \mu \mathrm{L})$ was injected onto a XBridge C18 column (Waters USA, 2.1 x $50 \mathrm{~mm}, 3.5 \mu \mathrm{m}$ particle diameter) using a guard column $(2.1 \times 10 \mathrm{~mm})$ of the same stationary phase. The eluent consisted of nanopure water (eluent A) and methanol (eluent B), both 
containing $0.1 \%(\mathrm{v} / \mathrm{v})$ formic acid. The LC gradient used for the separation was as follows: 0 - $4 \mathrm{~min}$, eluent B was increased from 10 - 50\%; 4 - $17 \mathrm{~min}$, eluent B was increased from $50-95 \%$, then continued at $95 \%$ for 8 minutes. Prior to the next injection, the column was re-equilibrated with $90 \%$ eluent $A$ and $10 \%$ eluent $B$ for 5 min. The eluent flow rate was $0.2 \mathrm{~mL} / \mathrm{min}$ at a temperature of $30{ }^{\circ} \mathrm{C}$.

\subsection{Detection and quantification using high resolution mass spectrometry (HRMS)}

Analytes were detected using a high resolution mass spectrometer ( $Q$ Exactive; Thermo Fisher Scientific Corporation, USA). Ionisation of analytes was achieved using electrospray ionisation (ESI) operated in both positive (+eV) and negative (-eV) modes. The ESI and HRMS settings are reported in Table S2, available in the Supporting Information. A screening analysis was conducted where the selected target analytes were recorded using $Q$ Exactive mass spectrometer full-scan spectra from 100-1000 m/z with a mass resolution (R) of 140,000 (@ 200 m/z) in positive and negative ionisation mode. For confirmation, all target analytes were fragmented in the HCD collision cell (high energy collision dissociation) using a data-dependent MS2 fragmentation approach. The top 5 MS2 spectra were measured in the Orbitrap mass analyser with a resolution of 17,500 , normalized collision energies ranged from $20-100 \%$.

\subsection{Data processing and quantification}

A target screening was conducted on the $Q$ Exactive raw data files using the software package enviMass $1.2^{15}$. Peak lists for each sample were generated from raw data files using the freely available peak picking software Formulator (rev3, Thermo Fisher Scientific). Parameters for both the enviMass 1.2 and the Formulator software are listed in Table S3-S4 available in the Supporting Information. Peak lists were then loaded into the enviMass1.2 software for a qualitative target screening of 291 target substances. Positive detects were manually reprocessed and quantified using the Xcalibur 2.2 QuanBrowser Software (Thermo Fisher Scientific). Quantification was performed with seven extracted standard samples containing all spiked target compounds with concentrations of $1,5,10,25,50,100 \mathrm{ng} / \mathrm{L}$ and a blind sample (extracted nanopure water with spiked internal standards mix).

For quality control, the relative SPE recoveries of the method were determined. One matrix sample constituted of post RO water was split in two equal portions. The first 
portion was spiked with $100 \mathrm{ng} / \mathrm{L}$ of standard mix and labelled surrogates while the second portion was treated as a blank and spiked with the labelled surrogates only, Both samples were treated exactly as the other samples in the batch. Relative deviations of recoveries within $\pm 30 \%$ were accepted (See Table S5 available in the Supporting Information).

All detected substances were confirmed using the data-dependend MS2 spectra which were compared against single substance injection MS2 spectra acquired in house with varying collision energies.

\section{Results and Discussion}

3.1 Compounds detected in RO treated water

Table 1. Concentration range (min-max) and median concentration ( $\mathrm{ng} / \mathrm{L}$ ) of detected target compounds in post RO and post UV water samples collected from Beenyup AWRP on four different days (16/01/12 - 19/01/12). The average UV removal with the relative standard deviation is also reported.

\begin{tabular}{|c|c|c|c|c|c|}
\hline \multirow[b]{2}{*}{ Chemicals } & \multicolumn{2}{|c|}{ Post RO samples } & \multicolumn{3}{|c|}{ Post UV samples } \\
\hline & $\begin{array}{c}\text { Concentration } \\
\text { range } \\
\text { min-max }\end{array}$ & Median & $\begin{array}{c}\text { Concentration } \\
\text { range } \\
\text { min-max }\end{array}$ & Median & $\begin{array}{l}\text { Average } \\
\text { UV } \\
\text { removal } \\
\text { (土RSD) }\end{array}$ \\
\hline $\begin{array}{c}\text { 4+5-Methyl- } \\
1 \mathrm{H}- \\
\text { benzotriazole }\end{array}$ & $750-900$ & 775 & $350-400$ & 375 & $53 \pm 6$ \\
\hline Benzotriazole & $750-1300$ & 800 & $375-550$ & 412 & $51 \pm 5$ \\
\hline Galaxalidone & $15-52.5$ & 29 & $5-30$ & 14 & $37 \pm 48$ \\
\hline Lamotrigin & $5-5$ & 5 & $2.5-5$ & 2.5 & $\mathrm{~N} / \mathrm{A}$ \\
\hline Metolachlor & $<1^{*}-7.5$ & 3.75 & $0.5^{* *}-5$ & 2.5 & N/A \\
\hline Metformin & $65-105$ & 99 & $87.5-110$ & 95 & $\mathrm{~N} / \mathrm{A}$ \\
\hline Propiconazole & $5-8$ & 7.5 & $2.5-7.5$ & 6.25 & $\mathrm{~N} / \mathrm{A}$ \\
\hline Prosulfocarb & $2.5^{\star *}-5$ & 5 & $<5^{*}-5$ & 5 & $\mathrm{~N} / \mathrm{A}$ \\
\hline Tramadol & $0.5^{* *}-475^{\star * *}$ & $0.5^{* *}$ & $0.5^{* *}-100^{* * *}$ & $\mathrm{~N} / \mathrm{A}$ & $\mathrm{N} / \mathrm{A}$ \\
\hline Acesulfame & $25-35$ & 26 & $<1^{*}-2.5$ & $\mathrm{~N} / \mathrm{A}$ & $95 \pm 2$ \\
\hline Saccharin & $<1^{*}-2.5$ & 2.5 & $<1^{*}-5$ & 5 & $\mathrm{~N} / \mathrm{A}$ \\
\hline Sucralose & $2.5-10$ & 10 & $2.5-10$ & 8.75 & N/A \\
\hline $\begin{array}{c}\text { Triethyl } \\
\text { phosphate }\end{array}$ & $200-200$ & 200 & $100-100$ & 100 & $50 \pm N / A$ \\
\hline
\end{tabular}

${ }^{*}$ LOQ; ${ }^{* *}$ tentatively quantified; N/A: not available; ${ }^{* * *}$ outlier 
The concentrations of detected chemicals in $\mathrm{RO}$ treated water are reported in Table 1. Only 13 of the 291 chemicals targeted (i.e. $\sim 4.5 \%$ ) were detected in RO water, although these chemicals were frequently detected in either 3 or 4 of the 4 sampling events. The chemicals detected included two corrosion inhibitors $(4+5-M e t h y l-1 \mathrm{H}-$ benzotriazole and benzotriazole), three pesticides (metolachlor, propiconazol, prosulfocarb), three pharmaceuticals (lamotrigin, metformin, tramadol), 1 personal care product metabolite (galaxalidone), three artificial sweeteners (acesulfame, saccharin and sucralose) and 1 industrial chemical (triethyl phosphate). Most chemicals were detected at a concentration less than $50 \mathrm{ng} / \mathrm{L}$. However, the corrosion inhibitors chemicals benzotriazole and 4+5-Methyl-1H-benzotriazole, the pharmaceutical metformin and the industrial chemical triethyl phosphate were detected at much higher concentrations, between 65 and $1300 \mathrm{ng} / \mathrm{L}$.

Benzotriazole and its derivatives, including 4+5-Methyl-1H-benzotriazole are high volume production chemicals, with an estimated worldwide production of benzotriazoles in excess of 9000 tons/year. ${ }^{16,17}$ They are commonly used in paints and polymers as UV absorbers, detergents, antifreeze, brake fluids and in aircraft de-icing fluids as corrosion inhibitors ${ }^{18}$ and they are extensively found in WW and the environment. ${ }^{19}$ They have been found to be acutely toxic to specific species, ${ }^{20}$ but their chronic toxicity is not well studied. Benzotriazole and $4+5-M e t h y l-1 \mathrm{H}-$ benzotriazole were consistently detected in relatively high concentration ranges in $\mathrm{RO}$ treated water, and this is expected given the $\mu \mathrm{g} / \mathrm{L}$ concentrations previously detected in Beenyup secondary treated WW, ${ }^{12}$ the relatively low MW (<150 Da) and the high water solubility and mobility $\left(\log \mathrm{K}_{\mathrm{ow}}=1.23\right.$ for benzotriazole and $\log \mathrm{K}_{\mathrm{ow}}=$ 1.89 for 4+5-Methyl-1H-benzotriazole, see Table S5 available in the Supporting Information). These results are also consistent with our previous findings, which showed benzotriazole and 4+5-Methyl-1H-benzotriazole concentrations in $\mathrm{RO}$ treated water averaging $974( \pm 28) \mathrm{ng} / \mathrm{L}$ and $416( \pm 34) \mathrm{ng} / \mathrm{L}$, respectively. ${ }^{12}$

Galaxolidone, is a metabolite of galaxolide, a polycyclic musk widely used as a fragrance in personal care and consumer products including cosmetics, cleaning agents, detergents, air fresheners and perfumes. ${ }^{21}$ Galaxolidone results from the degradation of the parent compound galaxolide during biological activated sludge. ${ }^{22,23}$ Given their high log $\mathrm{K}_{\mathrm{ow}}$ (5.9 and 5.3 respectively), both galaxolide and 
galaxolidone can concentrate in blood, fat ${ }^{24}$ and breast milk. ${ }^{25}$ Synthetic musks can affect androgen and progesterone receptors and also stimulate estrogenic receptors in humans. ${ }^{26}$ Polycyclic musks have been reported in water bodies and biota previously. ${ }^{27}$ The median concentration of galaxolidone in RO treated water was 29 $\mathrm{ng} / \mathrm{L}$. However, galaxalidone was also detected in the CWQRC laboratory blanks at $10 \mathrm{ng} / \mathrm{L}$ (data not shown). This contamination could have resulted from an accidental exposure of the laboratory blank to the chemical at the time of sample collection or during the sample preparation process. Galaxolide and its metabolite galaxalidone will preferentially absorb onto plastic and glass (i.e. SPE equipment) and therefore are prone to cross-contamination. Despite this cross-contamination issue, it is still likely that low $\mathrm{ng} / \mathrm{L}$ concentration of galaxolidone are present in $\mathrm{RO}$ treated water. The parent compound galaxolide was previously measured in wastewater and recycled samples from Beenyup WWTP and AWRP. ${ }^{11}$ Even though galaxolidone is neutral, based on the scheme proposed by Bellona et al. ${ }^{7}$ the physical-chemical properties of this chemical (MW > Molecular weight cut off (MWCO) of the membrane, approximately $150-200 \mathrm{Da}$, and $\log \mathrm{K}_{\mathrm{ow}}>2$ ), a moderate to high rejection is expected during RO treatment. Given the high volume of usage and high concentration of galaxolide in $\mathrm{WW}^{11}$ and the high hydrophobicity of galaxolidone, it may have accumulated on the membranes and eventually achieved breakthrough from diffusion phenomena. ${ }^{7}$

The median concentration of the industrial chemical triethyl phosphate in RO treated water was $200 \mathrm{ng} / \mathrm{L}$. Triethyl phosphate is a common flame retardant, a polymer resin modifier, a plasticizer (e.g. for unsaturated polyesters) and an intermediate in the manufacture of pesticides and other chemicals. ${ }^{28-30}$ It is used as an industrial catalyst (in acetic anhydride synthesis) and as a solvent (e.g. cellulose acetate), a stabilizer for peroxides, and a strength agent for rubber and plastics including vinyl polymers and unsaturated polyesters. ${ }^{28-30}$ Previously, we have detected a range of phosphate chemicals including triethyl phosphate, tris(chloropropyl) phosphate, tris(dichloropropyl) phosphate in wastewater samples from Beenyup WWTP. Furthermore, while all phosphate chemicals were below detection in samples collected post-RO treatment $(\mathrm{LOD}=100 \mathrm{ng} / \mathrm{L})$, they were all detected in the $\mathrm{RO}$ reject water. ${ }^{11}$ Further research is needed to better understand the occurrence of triethyl phosphate in wastewater and assess the rejection of this class of chemicals 
during UF/RO treatment. However, given the small molecular weight, the high pKa and the low log $\mathrm{K}_{\mathrm{ow}}$ (see Table S5) a poor rejection is expected for this compound. ${ }^{7}$

Out of 79 pesticides, 51 pesticides metabolites, 9 biocides and 2 biocides metabolites targeted, only 2 pesticides (metolachlor and prosulfocarb) and 1 biocide (propiconazole) were detected at very low concentrations in RO treated water. Interestingly, the pesticide metolachlor was also detected in our previous work, ${ }^{10}$ at similar concentrations, possibly indicating breakthrough during $\mathrm{RO}$ treatment. However, in this study metolachlor was detected in $100 \%$ of the samples tested (4 RO treated samples and 4 UV treated samples, see Table 1) compared to only $3 \%$ of the samples ( 1 sample out of 33 analysed) tested previously. ${ }^{10}$ The high frequency in the detection observed for metolachlor in this work may be due to the much lower LOD (1 $\mathrm{ng} / \mathrm{L})$ achieved in this study compared to the LOD (60 $\mathrm{ng} / \mathrm{L})$ achieved in the previous study. Propiconazole, the biocide detected in this work, was not detected previously, ${ }^{10}$ again possibly because the LOD $(5 \mathrm{ng} / \mathrm{L})$ achieved in this study was much lower than the LOD (100 $\mathrm{ng} / \mathrm{L}$ achieved in the previous study. Prosulfocarb was not analysed previously and therefore a comparison is not possible. All three pesticides have MW that is greater than the MWCO of the RO membranes and also possess $\log \mathrm{K}_{\mathrm{ow}}>2$. In this scenario, good removal is expected, although membrane breakthrough could be caused by partitioning/diffusion within the membrane. ${ }^{7}$

Only 3 pharmaceuticals of the 88 pharmaceuticals and 27 pharmaceutical metabolites (27 compounds) tested were detected in RO treated water. Lamotrigine is an anticonvulsant drug used in the treatment of epilepsy and bipolar disorder. ${ }^{31}$ It is also used off-label as an adjunct in treating depression. Tramadol is used similarly to codeine and it is a synthetic analgesic used to treat moderate to moderatelysevere pain. The drug has a wide range of applications, including treatment of rheumatoid arthritis, restless legs syndrome and fibromyalgia. ${ }^{32}$ Metformin is very commonly used for treatment of type 2 diabetes in obese and overweight people and it is listed as one (of only two) oral antidiabetics in the World Health Organization Model List of Essential Medicines. ${ }^{33}$ All 3 pharmaceuticals are registered for use and commonly sold in Australia. ${ }^{34}$ Concentration of lamotrigine and tramadol in RO treated water were below $5 \mathrm{ng} / \mathrm{L}$, with the exception of tramadol, which was measured at $475 \mathrm{ng} / \mathrm{L}$ in one sample (19/01/2012). The reason for such high 
concentration post RO treatment is not known. However, given that contamination from this compound (100 $\mathrm{ng} / \mathrm{L})$ was also seen in one laboratory blank, this single high detection level should be treated as an outlier. In contrast the median concentration of metformin over all RO treated water samples was $99 \mathrm{ng} / \mathrm{L}$. Metformin, is commonly found in water bodies due to its high volume usage. ${ }^{35}$ Moreover, given its relatively low molecular weight and high solubility (see Table S5), RO rejection is expected to be relatively poor. All 3 pharmaceuticals have been previously tested in Beenyup WWTP and Beenyup AWRP but were not detected in $\mathrm{RO}$ treated water possibly due to higher LOD. ${ }^{11}$

The 3 artificial sweeteners detected in RO treated water were acesulfame, sucralose and saccharin. While the presence of artificial sweeteners, a common constituent of low calorie food and beverages, in the aquatic environment has been reported in previous studies overseas, ${ }^{36-43}$ little has been reported regarding their presence within Australian waters. ${ }^{11}$ Recent studies have shown that artificial sweeteners are quite stable and persistent in the environment, and are excreted predominantly unchanged as waste from the body. ${ }^{36,39,40}$ Sucralose in particular, is resistant towards biodegradation, and as a result is persistent in WWTP. ${ }^{36,37,43}$ To the best of our knowledge, little has been reported regarding the behavior of artificial sweeteners during RO treatment. Acesulfame (MW = $162 \mathrm{Da})$ and saccharin (MW = $183 \mathrm{Da}$ ) both have molecular weights close to the MWCO of the RO membrane. Moreover both have high water solubility, ${ }^{42,44,45}$ meaning they are unlikely to adsorb on membranes and therefore poor rejection is expected ${ }^{7}$ (see Table S5). Furthermore, the presence of $\mu \mathrm{g} / \mathrm{L}$ concentrations in secondary WW feed to Beenyup AWRP may also play an important role in the detection of these sweeteners post RO treatment, as high concentrations in secondary WW have been linked to detection in RO treated water, even when RO rejection is high. ${ }^{10}$ Artificial sweeteners represent an ideal marker for wastewater contamination and the study of their behavior during RO treatment could significantly aid wastewater recycling and future management of groundwater replenishment.

\subsection{Compounds detected in UV treated water}

At Beenyup AWRP, the last treatment barrier is UV for pathogen inactivation. This barrier employs ITT Wedeco units (low pressure lamps, UV-C at 254nm, 4 UV units 
in series, dose of up to $50 \mathrm{~mJ} / \mathrm{cm}^{2}$ for each unit). Analysis of samples post-UV treatment showed that the concentration of some UV degradable compounds was reduced. Table 1 presents the concentration of chemicals detected in UV treated water as well the observed average removal after the UV treatment, calculated using the percentage difference in concentration between RO treated water and UV treated water for matched samples.

For both benzotriazole and 4+5-Methyl-1H-benzotriazole the UV treatment led to average removal of about $50 \%$ of the initial concentrations. This is in agreement with previous research showing benzotriazoles are prone to degradation by UV light (direct photolysis); benzotriazole and its derivatives are known UV absorbers, ${ }^{46,47}$ so degradation and reactivity of this class of chemicals was expected to be significant. For galaxolidone, a moderate but highly variable removal was achieved (average UV removal $=37 \pm 48 \%$ ). A significant and consistent reduction of the concentration of the artificial sweeteners acesulfame (average UV removal: $95 \pm 2 \%$ ) was also observed. The kinetic and the mechanism of degradation of this compound has previously been described in full, ${ }^{48}$ confirming the effectiveness of UV treatment to reduce the concentration of this compound in receiving waters. For triethyl phosphate the median UV removal was 50\%. For the remaining compounds detected in RO treated water, it was not always clear whether UV treatment reduced concentrations in the final product water as most concentrations were low and near the LOQ of the compound or in some case, the concentration detected post UV was higher than the concentration detected post RO.

Tertiary treatments such as UV for virus inactivation, as well as advanced oxidation processes including use of strong oxidants such as ozone, $\mathrm{H}_{2} \mathrm{O}_{2}+\mathrm{UV}$ and combination of them, usually result in the incomplete mineralisation of micropollutants, and the formation of mixtures of transformation by-products. ${ }^{49-51}$ The chemical structures, but more importantly the toxicological properties, of the transformation by-products arising from incomplete oxidation of micropollutants remains unknown for a wide range of chemicals although research in this area has been rapidly developing in the last decade. ${ }^{49-52}$ Nowadays, there is general consensus that whenever an oxidation process is applied to polish the final water, 
transformation by-products should be also assessed through non-target analysis and included in the risk assessment where possible. Further research into the integrated use of target/non-target chemical screening and bioassays as a monitoring tool for water recycling is recommended.

\subsection{Contribution of anthropogenic chemicals to the dissolved organic carbon}

Previous research characterized RO water in Perth, Western Australia for 375 anthropogenic chemicals, with 108 chemicals detected on at least one occasion, and 30 chemicals detected in more than $25 \%$ of all samples. ${ }^{5,10}$ However, assessment of the contribution of these detected chemicals to the DOC measured in RO treated water was only able to attribute 2.5 to $5 \%$ of the DOC to anthropogenic chemicals. ${ }^{10}$ One of the objectives of this present work was to assess whether analysis of an extended list of polar organic chemicals could help to account for the remaining DOC. In this study, the RO treated water was analysed for 291 chemicals, of which 248 chemicals have not been analysed previously at Beenyup AWRP. Out of these 291 chemicals, only 13 compounds $(\sim 4.5 \%)$ were detected. The contribution of anthropogenic chemicals to the residual DOC in post UV treated water was estimated using the same methodology described in Linge et al., in which DOC contribution is calculated using the percentage carbon in each detected molecule. ${ }^{10}$ Overall, the detection of these 13 compounds in the RO effluent could not account for the residual $\mathrm{DOC}$ in RO water, with the detected chemicals contributing between $0.6 \mu \mathrm{g} / \mathrm{L}$ (median value) to $1.3 \mu \mathrm{g} / \mathrm{L}$ (maximum value) of DOC. The DOC measured at Beenyup AWRP plant over the 4 days of sampling (16/01/12 - 19/01/12) averaged $58 \mu \mathrm{g} / \mathrm{L}$ and therefore, the total contribution of DOC from these anthropogenic chemicals remains very small $(1.0-2.3 \%)$.

\subsection{Screening Health Risk Assessment}

A screening health risk assessment was conducted using the concept of the risk quotient $(R Q)$, which is calculated as the ratio between the reported concentration of each chemical and the appropriate health values., ${ }^{5,10}$ Median and maximum concentrations of chemicals detected in post UV treated water were used to generate median and maximum RQs (Table 2). A risk quotient below one implies no health impact is expected. Health values for benzotriazole, metolachlor and metformin were taken from the Australian Guidelines for Water Recycling ${ }^{53}$ while a 
health value for propiconazole was taken from the Australian Drinking Water Guidelines. $^{54}$ The health value for tolyltriazoles (4+5-Methyl-1H-benzotriazole) is the value used for recycled water at Beenyup AWRP. ${ }^{55}$ No Australian derived water guidelines exist for the other chemicals detected in this study and therefore other approaches were used to determine health values. For the metabolite galaxolidone, the AGWR guideline for the parent compound galaxolide $(1750 \mu \mathrm{g} / \mathrm{L})$ was used, with the addition of an extra safety factor of ten. ${ }^{53}$ For triethyl phosphate, a health value of $1000 \mu \mathrm{g} / \mathrm{L}$ was used, as it belongs to the same class of phosphate flame retardants, including tri(dichlorisopropyl) phosphate, triphenyl phosphate; tris(2 chloroethyl)phosphate. ${ }^{53}$ For the pharmaceuticals lamotrigine and tramadol, health values were calculated from the lowest daily therapeutic dose (LDTD) ${ }^{56}$ using the approach outlined in the Australian Guidelines for Water Recycling: ${ }^{53}$

Health value $(\mu \mathrm{g} / \mathrm{L})=\left(\operatorname{LDTD}(\mathrm{mg} /\right.$ day $\left.) \times \mathrm{P} \times 10^{3}\right) /(\mathrm{SF} \times \mathrm{V}(\mathrm{L} /$ day $))$

where $P=$ proportion of LDTD estimated to come from drinking water $(100 \%) ; 10^{3}=$ unit conversion $\mathrm{mg} / \mathrm{L}$ to $\mu \mathrm{g} / \mathrm{L}$; SF: safety factor (1000 for most pharmaceuticals); $\mathrm{V}=$ volume of water drunk (2 L/day). Health values for the artificial sweeteners, acesulfame, saccharine and sucralose, ${ }^{44}$ and the pesticide prosulfocarb ${ }^{57}$ were all derived from acceptable daily intake values (ADI, expressed as $\mathrm{mg} / \mathrm{kg}$ body weight, assuming body weight $=70 \mathrm{~kg}$ ) as outlined in the Australian Guidelines for Water Recycling. ${ }^{53}$

Table 2. Screening health risk assessment for UV treated water reporting median and maximum risk quotients $\left(R Q_{\text {med }}\right.$ and $\left.R Q_{\max }\right)$.

\begin{tabular}{c|c|c|c|c} 
Chemicals & $\begin{array}{c}\text { Health } \\
\text { Value } \\
(\boldsymbol{\mu g} / \mathbf{L})\end{array}$ & $\mathbf{R Q}_{\text {med }}$ & $\mathbf{R Q}_{\max }$ & Reference \\
\hline $\begin{array}{c}4+5-M e t h y l-1 \mathrm{H}- \\
\text { benzotriazole }\end{array}$ & 20 & 0.019 & 0.020 & 55 \\
\hline Benzotriazole & 20 & 0.021 & 0.028 & 53 \\
\hline Galaxolidone & $175^{\mathrm{a}}$ & 0.000008 & 0.00002 & 53 \\
\hline Lamotrigine & $12.5^{\mathrm{b}}$ & 0.0002 & 0.0004 & 56 \\
\hline Metolachlor & 300 & 0.000008 & 0.00002 & 53 \\
\hline Metformin & 250 & 0.0004 & 0.0004 & 54 \\
\hline Propiconazole & 100 & 0.00006 & 0.000075 &
\end{tabular}




\begin{tabular}{c|c|c|c|c} 
Prosulfocarb & $0.175^{\mathrm{c}}$ & 0.028 & 0.028 & 57 \\
\hline Tramadol & $200^{\mathrm{b}}$ & N/A & 0.0000125 & 56 \\
\hline Acesulfame & $315^{\mathrm{c}}$ & N/A & 0.0000079 & ${ }^{44}$ \\
\hline Saccharin & $133^{\mathrm{c}}$ & 0.000037 & 0.000037 & ${ }^{44}$ \\
\hline Sucralose & $525^{\mathrm{c}}$ & 0.000016 & 0.000019 & ${ }^{44}$ \\
\hline Triethyl phosphate & $1000^{\mathrm{d}}$ & 0.0001 & 0.0001 & 53
\end{tabular}

${ }^{a}$ Galaxolidone, a metabolite of galaxolide, currently does not have a guideline value. The drinking water guideline for galaxolide $(1750 \mu \mathrm{g} / \mathrm{L})$ was used instead with an extra safety factor of ten. ${ }^{b}$ Drinking water guideline calculated from the lowest daily therapeutic dose (LDTD). ${ }^{\mathrm{c}}$ Drinking water guideline calculated from the acceptable daily intake (ADI). 'Drinking water guideline derived from similar phosphate flame retardants.

For all chemicals both $R Q_{\text {med }}$ and $R Q_{\max }$ were between 2 and 6 orders of magnitude below 1 implying a high degree of safety associated with human consumption of recycled water.

\section{Conclusions}

The target screening conducted in RO and UV treated water samples from Beenyup AWRP has shown the presence of small $(\mathrm{MW}<200 \mathrm{Da})$, hydrophilic species such as corrosion inhibitors (i.e. benzotriazole and 4+5-Methyl-1H-benzotriazole), pharmaceuticals (i.e. metformin), artificial sweeteners (i.e. acesulfame and saccharin) and industrial chemicals (i.e. triethyl phosphate). These chemicals were consistently found in all samples and could potentially be used as treatment performance indicators in future studies. Very low concentrations $(\mathrm{ng} / \mathrm{L})$ of pesticides (metolachlor, propiconazole and prosulfocarb), along with other pharmaceuticals (lamotrigine and tramadol) were also detected. The break-through during RO treatment of some of these relatively large (MW >250 Da) and hydrophobic (log Kow $>2$ ) chemicals could be due to diffusion/partitioning within the membrane. The UV treatment installed at Beenyup AWRP helped to reduced UV degradable compounds such as the corrosion inhibitors ( $>50 \%$ removal), the flame retardant triethyl phosphate ( $50 \%$ removal) and the artificial sweetener acesulfame ( $\sim 95 \%$ removal). Overall, the contribution of the detected anthropogenic chemicals to the DOC measured in post UV treated water was found to be minimal $(1.0-2.3 \%)$. The target screening analysis also show that a number of anthropogenic chemicals (i.e. 278 out 
of 291 compounds, >95.5\%) such as pesticides, biocides, industrial chemicals, pharmaceuticals and metabolites were not detectable in RO and UV treated water. A screening heath risk assessment showed that $R Q$ were generally 2 to 6 orders of magnitude below 1, implying a high degree of safety associated with human consumption of recycled water. Overall this chemical screening provides further evidence of the overall safety of the use of recycled wastewater treated by RO and UV as a potable water source, and it has confirmed that anthropogenic chemicals constitute a relatively small percentage of DOC in RO treated WW. However, the study also highlights the limitations of the traditional approach for assessing chemical safety, focused on end-product compliance testing for all potential chemicals. This approach is time consuming, expensive, and relies on the availability of appropriate health values for all chemicals tested. Given the time consuming nature of trace chemical analysis, further research into the use of bioassays as a monitoring tool for water recycling is recommended. ${ }^{11,58-61}$ Bioanalytical tools can screen for a wide range of contaminants and transformation products, based on biological effect, rather than monitoring specific chemicals, and may provide an efficient high-throughput tool broad screen assessment of water quality or hazard identification, and risk characterisation.

\section{Acknowledgements}

This work was undertaken in alignment with ARC Linkage Project 0989326 "Treating wastewater for potable reuse: removal of chemicals of concern using advanced oxidation processes" (Partner Organisations: Water Corporation of Western Australia, GHD Pty Ltd and WaterRA). We thank all project partners, especially the staff at the Water Corporation of Western Australia (B. Edwards, M. Handyside, P. Blair and S. Hamilton) for coordinating the site visits and sample collection.We also acknowledge the contribution of two anonymous reviewers to revision and improvement of the manuscript.

\section{Appendix A. Supplementary data}

Supplementary data associated with this article can be found at in the online version. 
Figure 1. Parents compounds, transformation products and metabolites assessed in the target screening analysis.

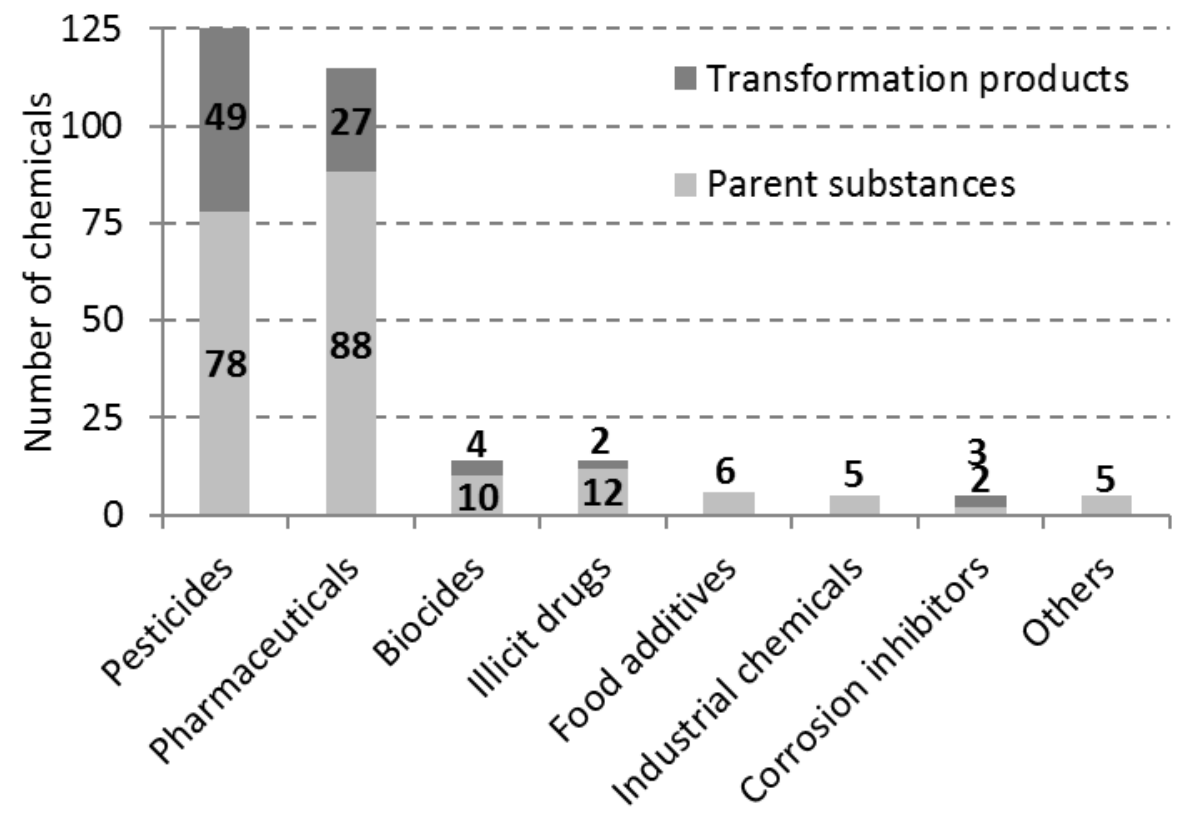

Figure 2. Schematic of Beenyup Wastewater Treatment Plant (WWTP) and Beenyup Advanced Water Recycling Plant (AWRP). Sampling points (i.e. 1-2) are also indicated. UF: ultrafiltration; RO: reverse osmosis; UV: UV disinfection; ML/d: mega litres per day.

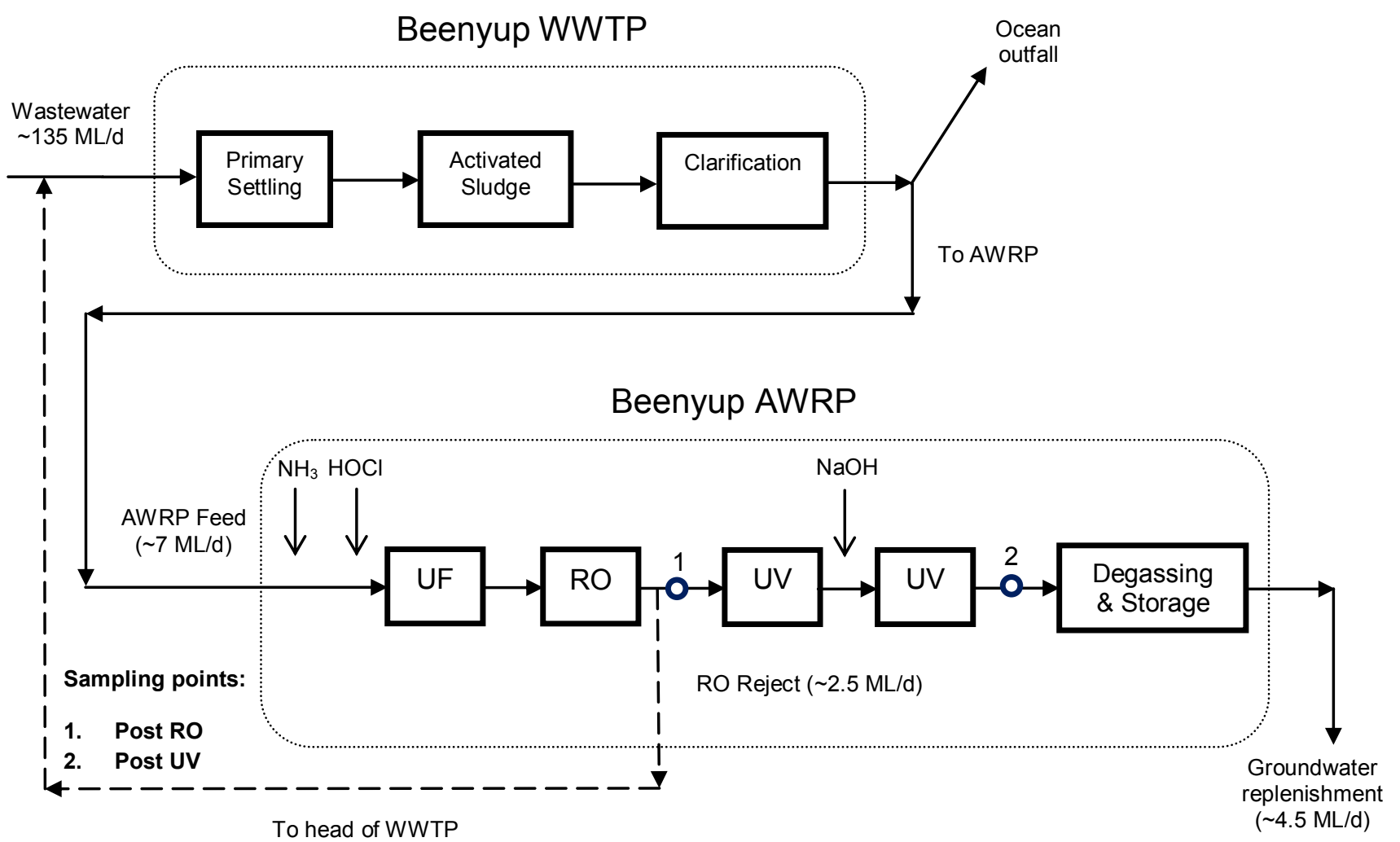




\section{Supporting Information}

Target Screening of Chemicals of Concern in Recycled Water

F. Busetti ${ }^{a, *}$, M. Ruff ${ }^{b}$ and K.L. Linge ${ }^{a}$

${ }^{a}$ Curtin Water Quality Research Centre, Department of Chemistry, Curtin University, GPO Box U1987, Perth, Western Australia 6845, Australia

${ }^{b}$ Eawag, Swiss Federal Institute of Aquatic Science and Technology, Ueberlandstrasse 133, 8600 Dubendorf, Switzerland

*Corresponding author: Curtin Water Quality Research Centre, Department of Chemistry, Curtin University, GPO Box U1987, Perth, Western Australia 6845, Australia. Tel.: +61 89266 3273; fax: +61 89266 230. E-mail address: f.busetti@curtin.edu.au (F.Busetti). 
Table S1. Summary of the chemicals targeted in post RO and post UV treated water at Beenyup AWRP.

\begin{tabular}{|c|c|c|c|c|c|c|}
\hline Chemical (labelled surrogate) & CAS-Nr. & Formula & $\begin{array}{l}\text { Exact } \\
\text { mass }\end{array}$ & $\begin{array}{l}\text { Ionisation } \\
\text { mode }\end{array}$ & LOQ & $\begin{array}{c}\text { metabolite of/ } \\
\text { sub-group }\end{array}$ \\
\hline \multicolumn{7}{|c|}{ PESTICIDES } \\
\hline $2,4-D\left(2,4-D^{13} C 6\right)$ & $94-75-7$ & $\mathrm{C} 8 \mathrm{H} 6 \mathrm{Cl} 2 \mathrm{O} 3$ & 219.9689 & - & 5 & herbicide \\
\hline Acetochlor & $34256-82-1$ & C14H20CINO2 & 269.1177 & + & 100 & herbicide \\
\hline Alachlor (Alachlor-d13) & $15972-60-8$ & $\mathrm{C} 14 \mathrm{H} 20 \mathrm{CINO} 2$ & 269.1177 & + & 100 & herbicide \\
\hline Aldicarb (Aldicarb-d3) & $116-06-3$ & $\mathrm{C} 7 \mathrm{H} 14 \mathrm{O} 2 \mathrm{~N} 2 \mathrm{~S}$ & 190.0776 & + & 10 & insecticide \\
\hline Asulam & $3337-71-1$ & C8H10N2O4S & 230.0356 & + & 20 & herbicide \\
\hline Atraton & $1610-17-9$ & $\mathrm{C} 9 \mathrm{H} 17 \mathrm{~N} 5 \mathrm{O}$ & 211.1428 & + & 1 & herbicide \\
\hline Atrazine (Atrazine-d5) & $1912-24-9$ & $\mathrm{C} 8 \mathrm{H} 14 \mathrm{Cl} 1 \mathrm{~N} 5$ & 215.0932 & + & 1 & herbicide \\
\hline Azoxystrobin & $131860-33-8$ & $\mathrm{C} 22 \mathrm{H} 17 \mathrm{~N} 3 \mathrm{O} 5$ & 403.1163 & + & 1 & fungicide \\
\hline Bentazone (Bentazone-d6) & $25057-89-0$ & $\mathrm{C} 10 \mathrm{H} 12 \mathrm{~N} 2 \mathrm{O} 3 \mathrm{~S}$ & 240.0563 & - & 0.5 & herbicide \\
\hline Bromazil & $314-40-9$ & $\mathrm{C} 9 \mathrm{H} 13 \mathrm{BrN} 2 \mathrm{O} 2$ & 260.0155 & + & 3 & herbicide \\
\hline Bromoxynil & $1689-84-5$ & $\mathrm{C} 7 \mathrm{H} 3 \mathrm{Br} 2 \mathrm{NO}$ & 276.8561 & - & 1 & herbicide \\
\hline Carbetamide & $16118-49-3$ & $\mathrm{C} 12 \mathrm{H} 16 \mathrm{~N} 2 \mathrm{O} 3$ & 236.1155 & - & 1 & herbicide \\
\hline Chloridazon (Chloridazon-d5) & $1698-60-8$ & $\mathrm{C} 10 \mathrm{H} 8 \mathrm{Cl} 1 \mathrm{~N} 3 \mathrm{O}$ & 221.035 & + & 2 & herbicide \\
\hline Chlortoluron (Chlorotoluron-d6) & $15545-48-9$ & $\mathrm{C} 10 \mathrm{H} 13 \mathrm{CIN} 2 \mathrm{O}$ & 212.0711 & + & 0.5 & herbicide \\
\hline Clomazone & $81777-89-1$ & $\mathrm{C} 12 \mathrm{H} 14 \mathrm{CINO} 2$ & 239.0708 & + & 1 & herbicide \\
\hline Cymoxanil & $57966-95-7$ & $\mathrm{C} 7 \mathrm{H} 10 \mathrm{~N} 4 \mathrm{O} 3$ & 198.0753 & + & 10 & fungicide \\
\hline Cyproconazole & $94361-06-5$ & C15H18CIN3O & 291.1133 & + & 10 & fungicide \\
\hline Cyprodinil & $121552-61-2$ & C14H15N3 & 225.126 & + & 10 & fungicide \\
\hline Desmedipham & $13684-56-5$ & $\mathrm{C} 16 \mathrm{H} 16 \mathrm{~N} 2 \mathrm{O} 4$ & 300.1105 & + & 20 & herbicide \\
\hline Diazinon (hydrolized)(Diazinon-d10) & $333-41-5$ & $\mathrm{C} 12 \mathrm{H} 21 \mathrm{~N} 2 \mathrm{O} 3 \mathrm{PS}$ & 304.1005 & + & n.q. & insecticide \\
\hline Dicamba (Dicamba-d3) & $1918-00-9$ & $\mathrm{C} 8 \mathrm{H} 6 \mathrm{Cl} 2 \mathrm{O} 3$ & 219.9699 & - & 20 & herbicide \\
\hline Dichlorprop (Dichlorprop-d6) & $120-36-5$ & $\mathrm{C} 9 \mathrm{H} 8 \mathrm{O} 3 \mathrm{Cl} 2$ & 233.9845 & - & 5 & herbicide \\
\hline Diflufenican (Diflufenican-d3) & $83164-33-4$ & $\mathrm{C} 19 \mathrm{H} 11 \mathrm{~F} 5 \mathrm{~N} 2 \mathrm{O} 2$ & 394.0735 & + & 70 & herbicide \\
\hline Dimethachlor & $50563-36-5$ & C13H18CINO2 & 255.1021 & + & 0.5 & herbicide \\
\hline Dimethenamid & 87674-68-8 & $\mathrm{C} 12 \mathrm{H} 18 \mathrm{CINO} 2 \mathrm{~S}$ & 275.0741 & + & 0.5 & herbicide \\
\hline Dinoseb & $88-85-7$ & $\mathrm{C} 10 \mathrm{H} 12 \mathrm{~N} 2 \mathrm{O} 5$ & 240.0741 & - & 5 & herbicide \\
\hline Epoxyconazole & $133855-98-8$ & $\mathrm{C} 17 \mathrm{H} 13 \mathrm{CIFN} 3 \mathrm{O}$ & 329.0726 & + & 10 & fungicide \\
\hline Ethofumesat & $26225-79-6$ & $\mathrm{C} 13 \mathrm{H} 18 \mathrm{O} 5 \mathrm{~S}$ & 286.0869 & + & 10 & herbicide \\
\hline Fenpropimorph & $67306-03-0$ & $\mathrm{C} 2 \mathrm{OH} 33 \mathrm{NO}$ & 303.2557 & + & 1 & fungicide \\
\hline Fipronil & $120068-37-3$ & $\mathrm{C} 12 \mathrm{H} 4 \mathrm{Cl} 2 \mathrm{~F} 6 \mathrm{~N} 4 \mathrm{O} 1 \mathrm{~S}$ & 435.9387 & + & 1 & insecticide \\
\hline
\end{tabular}


Fluazifop (free acid)

Fludioxonil

Flufenacet

Fluroxypyr (free acid)

Flusilazole

Foramsulfuron

Hexazinon

Imidacloprid

loxynil

Isoproturon (Isoproturon-d6)

Kresoxim-methyl

Linuron

MCPA (MCPA-d6)

$\mathrm{MCPB}$

Mecoprop (Mecoprop-d6)

Mesotrione (Mesotrione-d3)

Metalaxyl

Metamitron

Metazachlor

Metolachlor (Metolachlor-d6)

Metribuzin

Metsulfuron-methyl

Monuron

Napropamid

Nicosulfuron

Orbencarb

Pethoxamid

Phenmedipham

Pirimicarb

Prochloraz

Prometon

Propachlor

Propaquizafop

Prosulfocarb (Surrogate: Propiconazole-d5)

Pyraclostrobin

$69335-91-7$
$131341-86-1$
$142459-58-3$
$69377-81-7$
$85509-19-9$
$173159-57-4$
$51235-04-2$
$138261-41-3$
$1689-83-4$
$34123-59-6$
$143390-89-0$
$330-55-2$
$94-74-6$
$94-81-5$
$93-65-2$
$104206-82-8$
$57837-19-1$
$41394-05-2$
$67129-08-2$
$51218-45-2$
$21087-64-9$
$74223-64-6$
$150-68-5$
$15299-99-7$
$111991-09-4$
$34622-58-7$
$106700-29-2$
$13684-63-4$
$23103-98-2$
$67747-09-5$
$1610-18-0$
$1918-16-7$
$111479-05-1$
$52888-80-9$
$175013-18-0$




\begin{tabular}{|c|c|c|c|c|c|c|}
\hline Pyrimethanil & $53112-28-0$ & C12H13N3 & 199.1109 & + & 1 & fungicide \\
\hline Rimsulfuron & $122931-48-0$ & $\mathrm{C} 14 \mathrm{H} 17 \mathrm{~N} 5 \mathrm{O} 7 \mathrm{~S} 2$ & 431.0564 & + & 25 & herbicide \\
\hline Simazine (Simazine-d5) & $122-34-9$ & C7H12CIN5 & 201.0776 & + & 1 & herbicide \\
\hline Simeton & $673-04-1$ & $\mathrm{C} 8 \mathrm{H} 15 \mathrm{~N} 5 \mathrm{O}$ & 197.1271 & + & 0.25 & herbicide \\
\hline Sulcotrione (Sulcotrione-d3) & $99105-77-8$ & $\mathrm{C} 14 \mathrm{H} 13 \mathrm{Cl} 1 \mathrm{O} 5 \mathrm{~S}$ & 328.0167 & + & 20 & herbicide \\
\hline Tebuconazole & $107534-96-3$ & $\mathrm{C} 16 \mathrm{H} 22 \mathrm{CIN} 3 \mathrm{O}$ & 307.1446 & + & 15 & fungicide \\
\hline Tebutam (Tebutam-d4) & $35256-85-0$ & $\mathrm{C} 15 \mathrm{H} 23 \mathrm{NO}$ & 233.1774 & + & 2.5 & herbicide \\
\hline Terbumeton & $33693-04-8$ & $\mathrm{C} 10 \mathrm{H} 19 \mathrm{~N} 5 \mathrm{O}$ & 225.1584 & + & 0.5 & herbicide \\
\hline Terbutylazine (Terbutylazine-d5) & $5915-41-3$ & C9H16CIN5 & 229.1089 & + & 2 & herbicide \\
\hline Thifensulfuron-methyl & $79277-27-3$ & $\mathrm{C} 12 \mathrm{H} 13 \mathrm{~N} 5 \mathrm{O} 6 \mathrm{~S} 2$ & 387.0302 & - & 5 & herbicide \\
\hline Trinexapac-ethyl & $95266-40-3$ & $\mathrm{C} 13 \mathrm{H} 16 \mathrm{O} 5$ & 252.0992 & + & 3 & growth regulator \\
\hline Tritosulfuron & $142469-14-5$ & C13H9F6N5O4S & 445.0279 & + & 5 & herbicide \\
\hline \multicolumn{7}{|c|}{ PESTICIDE METABOLITES } \\
\hline 2,4-dimethylphenylformamide & $60397-77-5$ & $\mathrm{C} 9 \mathrm{H} 11 \mathrm{NO}$ & 149.0835 & + & 20 & Amitraz \\
\hline 2,6-Dichlorbenzamide & $2008-58-4$ & $\mathrm{C} 7 \mathrm{H} 5 \mathrm{Cl} 2 \mathrm{NO}$ & 188.9743 & + & 3 & $\begin{array}{l}\text { Dichlobenil } \\
\text { Thifensulfuron-methyl }\end{array}$ \\
\hline 3,5,6-Trichloro-2-pyridinole & $6515-38-4$ & $\mathrm{C} 5 \mathrm{H} 2 \mathrm{Cl} 3 \mathrm{NO}$ & 196.9202 & - & 1 & Chlorpyrifos \\
\hline 3,5-dibromo-4-hydroxybenzoic acid & $3337-62-0$ & $\mathrm{C} 7 \mathrm{H} 4 \mathrm{Br} 2 \mathrm{O} 3$ & 293.8533 & - & 2 & Bromoxynil \\
\hline 3-Phenoxybenzoic acid & $3739-38-6$ & $\mathrm{C} 13 \mathrm{H} 10 \mathrm{O} 3$ & 214.0624 & - & 5 & Permethrin \\
\hline Acetochlor-ESA & $187022-11-3$ & $\mathrm{C} 14 \mathrm{H} 21 \mathrm{NO} 5 \mathrm{~S}$ & 315.1135 & - & 1 & Acetochlor \\
\hline Acetochlor-OXA & $194992-44-4$ & $\mathrm{C} 14 \mathrm{H} 19 \mathrm{NO} 4$ & 265.132 & - & 1 & Acetochlor \\
\hline Alachlor-ESA & $142363-53-9$ & $\mathrm{C} 14 \mathrm{H} 21 \mathrm{NO} 5 \mathrm{~S}$ & 315.1135 & - & 1 & Alachlor \\
\hline Alachlor-OXA & $171262-17-2$ & $\mathrm{C} 14 \mathrm{H} 19 \mathrm{NO} 4$ & 265.132 & - & 1 & Alachlor \\
\hline Atrazin-Desethyl (Atrazin-desethyl-15N3) & $6190-65-4$ & C6H10CIN5 & 187.0619 & + & 2.5 & Atrazine \\
\hline Atrazin-Desisopropyl (Atrazine-desisopropyl-d5) & $1007-28-9$ & C5H8CIN5 & 173.0463 & + & 5 & Atrazine \\
\hline Atrazine-2-Hydroxy (Atrazine-2-Hydroxy-d5) & $2163-68-0$ & $\mathrm{C} 8 \mathrm{H} 15 \mathrm{~N} 5 \mathrm{O}$ & 197.1271 & + & 1 & Atrazine \\
\hline Atrazine-desethyl-2-hydroxy & 19988-24-0 & $\mathrm{C} 6 \mathrm{H} 11 \mathrm{~N} 5 \mathrm{O}$ & 169.0958 & + & 2 & Prometon/Atrazine \\
\hline Azoxystrobinic acid & $\mathrm{N} / \mathrm{A}$ & $\mathrm{C} 21 \mathrm{H} 15 \mathrm{~N} 3 \mathrm{O} 5$ & 389.1012 & + & 3 & Azoxystrobin \\
\hline Bifenoic acid & $53774-07-5$ & $\mathrm{C} 13 \mathrm{H} 7 \mathrm{Cl} 2 \mathrm{NO} 5$ & 326.9707 & - & 1 & Bifenox \\
\hline $\begin{array}{l}\text { Chloridazon-desphenyl (Chloridazon-desphenyl- } \\
{ }^{15} \mathrm{~N} 2 \text { ) }\end{array}$ & $6339-19-1$ & $\mathrm{C} 4 \mathrm{H} 4 \mathrm{CIN} 3 \mathrm{O}$ & 145.0047 & + & 200 & Chloridazon \\
\hline Chloridazon-methyl-desphenyl & $17254-80-7$ & $\mathrm{C} 5 \mathrm{H} 6 \mathrm{CIN} 3 \mathrm{O}$ & 159.0199 & + & 0.5 & Chloridazon \\
\hline
\end{tabular}


Dimethachlor-OXA

Dimethenamide-ESA

Dimethenamide-OXA

$\mathrm{N}, \mathrm{N}$-Dimethylaminosulfanilid (DMSA)

Fipronil-sulfide

Fipronil-sulfon

Flufenacet-ESA

Flufenacet-OXA

Isoproturon-didemethyl

Isoproturon-monodemethyl

Mesotrione-MNBA

Metamitron-Desamino

Metazachlor-ESA

Metazachlor-OXA

Metolachlor-ESA

Metolachlor-Morpholinon

Metolachlor-OXA

Metribuzin-Desamino

Metribuzin-Diketo

$\mathrm{N}$-(2,4-dimethylphenyl)-N-methylformamidin

N,N-dimethyl-N'-(4-methylphenyl)-sulfamid

Propachlor-ESA

Propachlor-OXA

Propazine-2-hydroxy

Pyrimidinole

Simazine-2-hydroxy

Sulcotrione-CMBA

Terbutylazine-2-hydroxy

Terbutylazine-desethyl

Terbutylazine-desethyl-2-hydroxy
1086384-49-7

205939-58-8

380412-59-9

4710-17-2

120068-36-2

201668-32-8

201668-31-7

56046-17-4

34123-57-4

110964-79-9

36993-94-9

172960-62-2

N/A

171118-09-5

120375-14-6

152019-73-3

35045-02-4

56507-37-0

33089-74-6

66840-71-9

123732-85-4

70628-36-3

7374-53-0

2814-20-2

2599-11-3

53250-83-2

66753-07-9

30125-63-4

30125-63-4
120067-83-6

C13H17NO4

C12H19N1O5S2

C12H17NO4S

$\mathrm{C} 8 \mathrm{H} 12 \mathrm{~N} 2 \mathrm{O} 2 \mathrm{~S}$

$\mathrm{C} 12 \mathrm{H} 4 \mathrm{Cl} 2 \mathrm{~F} 6 \mathrm{~N} 4 \mathrm{~S}$

$\mathrm{C} 12 \mathrm{H} 4 \mathrm{Cl} 2 \mathrm{~F} 6 \mathrm{~N} 4 \mathrm{O} 2 \mathrm{~S}$

C11H14FNO4S

C11H12FNO3

C10H14N2O

$\mathrm{C} 11 \mathrm{H} 16 \mathrm{~N} 2 \mathrm{O}$

C8H7NO6S

C10H9N3O

C14H17N3O4S

$\mathrm{C} 14 \mathrm{H} 15 \mathrm{~N} 3 \mathrm{O} 3$

C15H23NO5S

C14H19NO2

$\mathrm{C} 15 \mathrm{H} 21 \mathrm{NO} 4$

$\mathrm{C} 8 \mathrm{H} 13 \mathrm{~N} 3 \mathrm{OS}$

$\mathrm{C} 7 \mathrm{H} 12 \mathrm{~N} 4 \mathrm{O} 2$

$\mathrm{C} 10 \mathrm{H} 14 \mathrm{~N} 2$

$\mathrm{C} 9 \mathrm{H} 14 \mathrm{~N} 2 \mathrm{O} 2 \mathrm{~S}$

$\mathrm{C} 11 \mathrm{H} 15 \mathrm{NO} 4 \mathrm{~S}$

C11H13N1O3

$\mathrm{C} 9 \mathrm{H} 17 \mathrm{~N} 5 \mathrm{O}$

$\mathrm{C} 8 \mathrm{H} 12 \mathrm{~N} 2 \mathrm{O}$

C7H13N5O

$\mathrm{C} 8 \mathrm{H} 7 \mathrm{Cl} 1 \mathrm{O} 4 \mathrm{~S}$

$\mathrm{C} 9 \mathrm{H} 17 \mathrm{~N} 5 \mathrm{O}$

$\mathrm{C} 7 \mathrm{H} 12 \mathrm{Cl} 1 \mathrm{~N} 5$

C7H13N5O

PHARMACEUTI

4-Dimethylaminoantipyrine

Albuterol

Amisulpride (Amisulpride-d5)

Amitriptylin
58-15-1

18559-94-9

71675-85-9

50-48-6

\section{$\mathrm{C} 13 \mathrm{H} 17 \mathrm{~N} 3 \mathrm{O}$}

$\mathrm{C} 13 \mathrm{H} 21 \mathrm{NO} 3$

C17H27N3O4S

$\mathrm{C} 2 \mathrm{OH} 23 \mathrm{~N}$
251.1158

321.0699

271.0873

200.0614

419.9438

451.9336

275.0622

225.0796

178.1101

192.1257

244.9989

187.0746

323.0934

273.1108

329.1291

233.141

279.1465

199.0774

184.0966

162.1152

214.077

257.0716

207.089

211.1428

152.095

183.1115

233.9748

211.1428

201.0776

183.1115
Dimethenamide

1 Dimethenamide

1.5 Dichlofluanid

1 Fipronil

2.5 Fipronil

1 Flufenacet

1 Flufenacet

1 Isoproturon

1 Isoproturon

75 Mesotrion

1.5 Metamitron

5 Metazachlor

5 Metazachlor

1 Metolachlor

1 Metolachlor

1.5 Metolachlor

0.5 Metribuzin

25 Metribuzin

5 Amitraz

0.5 Tolyfluanid

1 Propachlor

3 Propachlor

5 Propazine

30 Diazinon

1 Simazine

20 Sulcotrione

5 Terbutylazine

0.5 Terbutylazine

1 Terbutylazine 
Atenolol (Atenolol-d7)

Atomoxetine (Atomoxetine-d3)

Atorvastatine

Azithromycin (Azithromycin-d3)

Bezafibrate (Bezafibrate-d4)

Bicalutamide

Bupropion

Candesartan

Carbamazepine (Carbamazepine- ${ }^{13} \mathrm{C}$, d2)

Cetrizine

Cilastatin

Citalopram (Citalopram-d6)

Clarithromycin (Clarithromycin-d3)

Clindamycin

Clopidogrel (Clopidogrel-d4)

Clozapine (Clozapine-d8)

Cyclophosphamide (Cyclophosphamide-d4)

Cytarabine

Dexamethasone

Dextromethorphan

Diclofenac (Diclofenac-d4)

Dronedarone

Ephedrine

Eprosartan (Eprosartan-d3)

Ethambutole

Exemestane

Fenofibrate (Fenofibrate-d6)

FK-506 (Tacrolimus)

Fluconazole (Fluconazole-d4)

Fluoxetine (Fluoxetine-d5)

Furosemide (Furosemide-d5)

Gabapentin (Gabapentin-d4)

Gemcitabine (Gemcitabine- $-{ }^{13} \mathrm{C}$, d2)

Hydrochlorothiazide

Ibuprofen (Ibuprofen-d3)

$\begin{array}{llrrr}29122-68-7 & \text { C14H22N2O3 } & 266.1625 & + & 1 \\ 83015-26-3 & \text { C17H21NO } & 255.1623 & + & 1 \\ 134523-03-8 & \text { C33H35FN2O5 } & 558.253 & + & 50 \\ 83905-01-5 & \text { C38H72N2O12 } & 748.508 & + & 2.5 \\ 41859-67-0 & \text { C19H20CINO4 } & 361.1075 & + & 2.5 \\ 90357-06-5 & \text { C18H14F4N2O4S } & 430.061 & - & 10 \\ 34911-55-2 & \text { C13H18CINO } & 239.1077 & + & 1 \\ 139481-59-7 & \text { C24H20N6O3 } & 440.1597 & + & 10 \\ 298-46-4 & \text { C15H12N2O } & 236.0944 & + & 1 \\ 83881-52-1 & \text { C21H25CIN2O3 } & 388.1554 & + & 15 \\ 82009-34-5 & \text { C16H26N2O5S } & 358.1562 & + & n . q . \\ 59729-33-8 & \text { C20H21FN2O } & 324.1638 & + & 1 \\ 81103-11-9 & \text { C38H69NO13 } & 747.4763 & + & 5 \\ 18323-44-9 & \text { C18H33CIN2O5S } & 424.1798 & + & 5 \\ 144457-28-3 & \text { C15H14CINO2S } & 307.0439 & + & 5 \\ 5786-21-0 & \text { C18H19CIN4 } & 326.1298 & + & 10 \\ 50-18-0 & \text { C7H15CI2N2O2P } & 260.0248 & + & 10 \\ 147-94-4 & \text { C9H13N3O5 } & 243.085 & + & 10 \\ 50-02-2 & \text { C22H29FO5 } & 392.1999 & + & 5 \\ 125-71-3 & \text { C18H25NO } & 271.1936 & + & 2.5 \\ 15307-86-5 & \text { C14H11CI2NO2 } & 295.0161 & + & 5 \\ 141626-36-0 & \text { C31H44N2O5S } & 556.2971 & + & n . q . \\ 299-42-3 & \text { C10H15NO } & 165.2345 & + & 2 \\ 133040-01-4 & \text { C23H24N2O4S } & 424.1457 & + & 5 \\ 1070-11-7 & \text { C10H24N2O2 } & 204.1838 & + & n . q . \\ 107868-30-4 & \text { C20H24O2 } & 296.1771 & + & 1 \\ 49562-28-9 & \text { C20H21CI1O4 } & 360.1123 & + & 100 \\ 104987-11-3 & \text { C44H69NO12 } & 803.482 & - & 50 \\ 86386-73-4 & \text { C13H12F2N6O } & 306.1035 & + & 10 \\ 54910-89-3 & \text { C17H18F3NO } & 309.1335 & + & 2 \\ 54-31-9 & \text { C12H11CIN2O5S } & 330.0077 & - & 30 \\ 60142-96-3 & \text { C9H17NO2 } & 171.1259 & + & 50 \\ 95058-81-4 & \text { C9H11F2N3O4 } & 263.0718 & + & 50 \\ 58-93-5 & \text { C7H8CIN3O4S2 } & 296.9645 & - & 10 \\ 15687-27-1 & \text { C13H18O2 } & 206.1301 & + & 25\end{array}$


Ifosfamide

Indomethacin (Indomethacin-d4)

lobitridol

Iohexol

lopromide

Ketamine

Ketoprofen

Lamotrigine (Surrogate: Atrazine-desethyl-d5)

Levamisole

Levetiracetam (Levetiracetam-d3)

Lidocaine (Lidocaine-d10)

Mefenamic acid (Mefenamic acid-d3)

Metformin (Metformin-d6)

Methylprednisolone (Methylprednisolone-d4)

Metoclopramide

Metoprolol (Metoprolol-d7)

Metronidazole

Moclobemide

Mycophenolic acid

Naltrexon

Naproxen (Naproxen-d3)

Oseltamivir

Paracetamol (Paracetamol-d4)

Phenazone (Phenazone-d3

Pravastatin (Pravastatin-d3)

Prednisolon

Primidone (Primidone-d5)

Propranolol (Propranolol-d7)

Ranitidine (Ranitidine-d6)

Ritonavir (Ritonavir-d6)

Rosuvastatin

Roxithromycin

Sitagliptin

Sotalol (Sotalol-d6)

Sulfadiazine (Sulfadiazine-d4)
3778-73-2

53-86-1

136949-58-1

66108-95-0

73334-07-3

6740-88-1

22071-15-4

84057-84-1

14769-73-4

102767-28-2

137-58-6

61-68-7

657-24-9

83-43-2

$7232-21-5$

37350-58-6

443-48-1

71320-77-9

24280-93-1

16590-41-3

22204-53-1

196618-13-0

103-90-2

60-80-0

81093-37-0

50-24-8

125-33-7

525-66-6

66357-35-5

155213-67-5

287714-41-4

80214-83-1

486460-32-6

3930-20-9

68-35-9
C7H15Cl2N2O2P

$\mathrm{C} 19 \mathrm{H} 16 \mathrm{CINO} 4$

C2OH28I3N3O9

C19H26I3N3O9

C18H24I3N3O8

C13H16CINO

$\mathrm{C} 16 \mathrm{H} 14 \mathrm{O} 3$

$\mathrm{C} 9 \mathrm{H} 7 \mathrm{Cl} 2 \mathrm{~N} 5$

C11H12N2S

$\mathrm{C} 8 \mathrm{H} 14 \mathrm{~N} 2 \mathrm{O} 2$

$\mathrm{C} 14 \mathrm{H} 22 \mathrm{~N} 2 \mathrm{O}$

$\mathrm{C} 15 \mathrm{H} 15 \mathrm{NO} 2$

$\mathrm{C} 4 \mathrm{H} 11 \mathrm{~N} 5$

$\mathrm{C} 22 \mathrm{H} 30 \mathrm{O} 5$

$\mathrm{C} 14 \mathrm{H} 22 \mathrm{CIN} 3 \mathrm{O} 2$

$\mathrm{C} 15 \mathrm{H} 25 \mathrm{NO} 3$

C6H9N3O3

C13H17CIN2O2

$\mathrm{C} 17 \mathrm{H} 20 \mathrm{O} 6$

$\mathrm{C} 2 \mathrm{OH} 23 \mathrm{NO} 4$

$\mathrm{C} 14 \mathrm{H} 14 \mathrm{O} 3$

$\mathrm{C} 16 \mathrm{H} 28 \mathrm{~N} 2 \mathrm{O} 4$

$\mathrm{C} 8 \mathrm{H} 9 \mathrm{NO} 2$

$\mathrm{C} 11 \mathrm{H} 12 \mathrm{~N} 2 \mathrm{O}$

$\mathrm{C} 23 \mathrm{H} 36 \mathrm{O} 7$

$\mathrm{C} 21 \mathrm{H} 28 \mathrm{O} 5$

$\mathrm{C} 12 \mathrm{H} 14 \mathrm{~N} 2 \mathrm{O} 2$

$\mathrm{C} 16 \mathrm{H} 21 \mathrm{NO} 2$

C13H22N4O3S

C37H48N6O5S2

C22H28FN3O6S

C41H76N2O15

C16H15F6N5O

C12H2ON2O3S

$\mathrm{C} 10 \mathrm{H} 10 \mathrm{~N} 4 \mathrm{O} 2 \mathrm{~S}$
260.0248

357.0768

834.896

820.8798

790.8692

237.092

254.0937

255.0079

204.0721

170.1055

234.1732

241.1097

129.1014

374.2093

299.1401

267.1829

171.0638

268.0979

320.126

341.1627

230.0937

312.2044

151.0628

188.0944

424.2461

360.1937

218.105

259.1567

314.1407

720.3128

481.1683

836.524

407.1181

272.1189

250.0519
3

10

2000

1000

100

0.5

25

2.5

1.5

2.5

20

5

1

5

1

10

1

10

2.5

10

15

5

0.5

5

10

5

5

10

5 
122-11-2 C12H14N4O4S

$57-68-1$

Sulfamethazine (Sulfamethazine- ${ }^{13} \mathrm{C} 6$ )

Sulfamethoxazole (Sulfamethoxazole-d4)

Sulfapyridine (Sulfapyridine-d4)

Sulfathiazole (Sulfathiazole-d4)

Telmisartan

Thiopental

Tramadol (Tramadol-d6)

Trimethoprim (Trimethoprim-d9)

Trimipramin

Tylosin

Valsartan (Valsartan- ${ }^{15} \mathrm{~N},{ }^{13} \mathrm{C} 5$ )

Venlafaxine (Venlafaxine-d6)

Verapamil (Verapamil-d6)

2',3'-di-O-acetyl-5'-desoxy-5-fluorocytidine

4-(Trifluoromethyl)phenol

4-Acetamidoantipyrine

4-Formylaminoantipyrine

AMDOPH

Atenolol-desisopropyl

Atenololic acid (Atenolol acid-d5)

Carbamazepine-10,11-dihydro-10,11-dihydroxy

Carbamazepine-10,11-epoxide (Carbamazepine

10, 11-Epoxide- ${ }^{13} \mathrm{C}, \mathrm{d} 2$ )

Clofibric acid (Clofibric acid-d4)

D617

Fenofibrinic acid

Iminostilbene

$\mathrm{N}, \mathrm{N}$-Didesvenlafaxine

$\mathrm{N}, \mathrm{O}$-Didesvenlafaxine

N4-Acetyl-Sulfadiazine

N4-Acetyl-Sulfadimethoxine

N4-Acetyl-Sulfamethazine

N4-Acetyl-Sulfamethoxazole (N4-Acetyl-
723-46-6

144-83-2

72-14-0

$144701-48-4$

$76-75-5$

27203-92-5

$738-70-5$

739-71-9

1401-69-0

137862-53-4

93413-69-5

152-11-4

\section{PHARMACEUTICAL METABOLITES}

161599-46-8

402-45-9

83-15-8

1672-58-8

519-65-3

81346-71-6

56392-14-4

58955-93-4

36507-30-9

882-09-7

34245-14-2

42017-89-0

256-96-2

93413-77-5

$135308-74-6$

127-74-2

24341-30-8

100-90-3

21312-10-7
$\mathrm{C} 12 \mathrm{H} 14 \mathrm{~N} 4 \mathrm{O} 2 \mathrm{~S}$

C10H11N3O3S

C11H11N3O2S

C9H9N3O2S2

$\mathrm{C} 33 \mathrm{H} 30 \mathrm{~N} 4 \mathrm{O} 2$

C11H18N2O2S

$\mathrm{C} 16 \mathrm{H} 25 \mathrm{NO} 2$

C14H18N4O3

$\mathrm{C} 2 \mathrm{OH} 26 \mathrm{~N} 2$

$\mathrm{C} 46 \mathrm{H} 77 \mathrm{NO} 17$

$\mathrm{C} 24 \mathrm{H} 29 \mathrm{~N} 5 \mathrm{O} 3$

$\mathrm{C} 17 \mathrm{H} 27 \mathrm{NO} 2$

C13H16FN3O6

C7H5F3O

C13H15N3O2

$\mathrm{C} 13 \mathrm{H} 17 \mathrm{~N} 3 \mathrm{O} 3$

$\mathrm{C} 11 \mathrm{H} 16 \mathrm{~N} 2 \mathrm{O} 3$

$\mathrm{C} 14 \mathrm{H} 21 \mathrm{~N} 1 \mathrm{O} 4$

C15H14N2O3

$\mathrm{C} 15 \mathrm{H} 12 \mathrm{~N} 2 \mathrm{O} 2$

$\mathrm{C} 10 \mathrm{H} 11 \mathrm{ClO} 3$

$\mathrm{C} 17 \mathrm{H} 26 \mathrm{~N} 2 \mathrm{O} 2$

$\mathrm{C} 17 \mathrm{H} 15 \mathrm{ClO} 4$

$\mathrm{C} 14 \mathrm{H} 11 \mathrm{~N}$

C15H23N1O2

$\mathrm{C} 15 \mathrm{H} 23 \mathrm{~N} 1 \mathrm{O} 2$

C12H12N4O3S

C14H16N4O5S

C14H16N4O3S

C12H13N3O4S
C12H13N3O2

$\begin{array}{rrr}310.073 & + & 2.5 \\ 278.0832 & + & 3 \\ 253.0516 & + & 5 \\ 249.0566 & + & 5 \\ 255.0131 & + & 5 \\ 514.2369 & + & 100 \\ 242.1089 & - & 15 \\ 263.1885 & + & 1 \\ 290.1373 & + & 2 \\ 294.2096 & + & 1 \\ 915.5186 & + & 50 \\ 435.227 & + & 5 \\ 277.2036 & + & 0.5 \\ 454.2826 & + & 2\end{array}$

454.2826

329.1023

162.0287

245.117

231.1008

263.127

224.1161

267.1465

270.1004

252.0899

214.0391

290.1994

318.0653

193.0892

249.1729

249.1729

292.0625

352.0836

320.0938

295.0621
2

$+$

$+$

$+$

$+$

$+$

$+$

$+$

$-$

$+$

$+$

$+$

$+$

$+$

$+$

$+$

$+$
5

10 Capecitabin

50 Fluoxetin

1 Aminopyrine/Metamizol

1.5 Aminopyrine/Metamizol

0.5 Aminopyrine

50 Atenolol

1 Atenolol/Metoprolol

5 Carbamazepine

1 Carbamazepine

1 Clofibrate

0.5 Verapamil

2.5 Fenofibrate

Carbamazepine

5 Venlafaxine

5 Venlafaxine

5 Sulfadiazine

4 Sulfadimethoxine

2.5 Sulfamethazine

3 Sulfamethoxazole 
Sulfamethoxazole-d5)

N4-Acetyl-Sulfathiazole (N4-Acetyl-

Sulfathiazole-d4)

127-76-4

149289-30-5

93413-62-8

O-Desvenlafaxine

Oseltamivir-carboxylate

Ranitidine-N-oxide

Ranitidine-S-oxide

Ritalinic acid (Ritalinic acid-d10)

Valsartan acid (Valsartan acid-d4)

$187227-45-8$

738557-20-2

73851-70-4

19395-41-6

164265-78-5
2-Aminobenzimidazol

2-n-Octyl-4-isothiazolin-3-on

4,5-Dichloro-2-n-octyl-isothiazol-3(2H)-on

Carbendazim (Carbendazim-d4)

Diuron (Diuron-d6)

Diuron-desdimethyl

Diuron-desmonomethyl

Irgarol (Irgarol-d9)

Irgarol-descyclopropyl

N,N-diethyl-3-methylbenzamid

Prometryn

Propiconazole (Propiconazole-d5)

Terbutryn (Terbutryn-d5)

Triclosan (Triclosan-d3)

1-(3-Chlorophenyl)-piperazine

1-(3-Trifluoromethylphenyl)-piperazine

1-Benzylpiperazine

Amphetamine

Benzoylecgonine

Cocaine

Codeine (Codeine- ${ }^{13} \mathrm{C}, \mathrm{d} 3$ )

934-32-7

26530-20-1

64359-81-5

10605-21-7

330-54-1

2327-02-8

3567-62-2

28159-98-0

N/A

134-62-3

7287-19-6

60207-90-1

886-50-0

$3380-34-5$

\section{0-24-0}

$15532-75-9$

2759-28-6

300-62-9

519-09-5

$50-36-2$

$76-57-3$

$\begin{array}{ll}\mathrm{C} 11 \mathrm{H} 11 \mathrm{~N} 3 \mathrm{O} 3 \mathrm{~S} 2 & 297.0236 \\ \mathrm{C} 16 \mathrm{H} 25 \mathrm{~N} 1 \mathrm{O} 2 & 263.1885 \\ \mathrm{C} 16 \mathrm{H} 25 \mathrm{~N} 1 \mathrm{O} 2 & 263.1885 \\ \mathrm{C} 14 \mathrm{H} 24 \mathrm{~N} 2 \mathrm{O} 4 & 284.1731 \\ \mathrm{C} 13 \mathrm{H} 22 \mathrm{~N} 4 \mathrm{O} 4 \mathrm{~S} & 330.1362 \\ \mathrm{C} 13 \mathrm{H} 22 \mathrm{~N} 4 \mathrm{O} 4 \mathrm{~S} & 330.1362 \\ \mathrm{C} 13 \mathrm{H} 17 \mathrm{NO} 2 & 219.1254\end{array}$

$+$

$+$

$+$

$+$

$+$

$+$

C14H10N4O2 BIOCIDES and METABOLITES

\section{ILLICIT DRUGS and METABOLITES}

C7H7N3

C11H19NOS

C11H17Cl2NOS

$\mathrm{C} 9 \mathrm{H} 9 \mathrm{~N} 3 \mathrm{O} 2$

$\mathrm{C} 9 \mathrm{H} 10 \mathrm{Cl} 2 \mathrm{~N} 2 \mathrm{O}$

$\mathrm{C} 7 \mathrm{H} 6 \mathrm{Cl} 2 \mathrm{~N} 2 \mathrm{O}$

$\mathrm{C} 8 \mathrm{H} 8 \mathrm{Cl} 2 \mathrm{~N} 2 \mathrm{O}$

C11H19N5S

C8H15N5S

C12H17NO

C10H19N5S

C15H17Cl2N3O2

C10H19N5S

$\mathrm{C} 12 \mathrm{H} 7 \mathrm{Cl} 3 \mathrm{O} 2$

C10H13CIN2

C11H13F3N2

C11H16N2

$\mathrm{C} 9 \mathrm{H} 13 \mathrm{~N}$

C16H19NO4

$\mathrm{C} 17 \mathrm{H} 21 \mathrm{NO} 4$

$\mathrm{C} 18 \mathrm{H} 21 \mathrm{NO} 3$
266.0804

213.1182

281.0402

191.0689

232.0165

203.9852

218.0008

253.1356

213.1043

191.1305

241.1356

341.0692

241.1356

287.9506

$+$

$+$

$+$

$+$

196.0767

230.1031

176.1313

135.1048

289.1314

303.1471

299.1521

$+$

$+$

$+$

$+$

$+$

$+$

10 Sulfathiazole

0.5 Venlafaxine

1 Venlafaxine

10 Oseltamivir

2 Ranitidine

20 Ranitidine

5 Methylphenidat Valsartan, Losartan,

Candesartan,

5 Irbesartan

$133.0634+5 \quad 5$ Carbendazim

$+1$

$+25$

$+3$

$+$

$+1$

5

5 Diuron

+5 Diuron

$\begin{array}{ll}+ & 5 \\ + & 2\end{array}$

$+$

1 Irgarol

1

0.5

0.5
5

0.5

Carbendazim

- $\quad 25$

5

20

50

3

2.5 Cocaine

2.5
1
1 


\begin{tabular}{|c|c|c|c|c|c|c|}
\hline Diazepam (Diazepam-d5) & $439-14-5$ & $\mathrm{C} 16 \mathrm{H} 13 \mathrm{CIN} 2 \mathrm{O}$ & 284.0716 & + & 1 & \\
\hline 2-Ethyliden-1,5-dimethyl-3,3-diphenylpyrrolidine & $30223-73-5$ & $\mathrm{C} 2 \mathrm{OH} 23 \mathrm{~N}$ & 277.183 & + & 5 & Methadone \\
\hline Mephedrone & $1189805-46-6$ & $\mathrm{C} 11 \mathrm{H} 15 \mathrm{NO}$ & 177.1154 & + & 5 & \\
\hline Methadone & $76-99-3$ & $\mathrm{C} 21 \mathrm{H} 27 \mathrm{NO}$ & 309.2093 & + & 0.5 & \\
\hline Methamphetamine & $537-46-2$ & $\mathrm{C} 10 \mathrm{H} 15 \mathrm{~N}$ & 149.1204 & + & 1 & \\
\hline Morphine (Morphine-d3) & $57-27-2$ & $\mathrm{C} 17 \mathrm{H} 19 \mathrm{NO} 3$ & 285.1359 & + & 2.5 & \\
\hline Oxazepam (Oxazepam-d5) & $604-75-1$ & $\mathrm{C} 15 \mathrm{H} 11 \mathrm{CIN} 2 \mathrm{O} 2$ & 286.048 & + & 2.5 & \\
\hline \multicolumn{7}{|c|}{ FOOD ADDITIVES (Artificial Sweeteners) } \\
\hline Acesulfame (Acesulfame-d4) & $55589-62-3$ & $\mathrm{C} 4 \mathrm{H} 5 \mathrm{NO} 4 \mathrm{~S}$ & 162.9939 & - & 1 & \\
\hline Aspartame (Aspartame-d5) & $22839-47-0$ & $\mathrm{C} 14 \mathrm{H} 18 \mathrm{~N} 2 \mathrm{O} 5$ & 294.121 & + & 70 & \\
\hline Cyclamate (Cyclamate-d11) & $100-88-9$ & $\mathrm{C} 6 \mathrm{H} 13 \mathrm{NO} 3 \mathrm{~S}$ & 179.0616 & - & 1.5 & \\
\hline Neotame (Neotane-d3) & $165450-17-9$ & $\mathrm{C} 2 \mathrm{OH} 30 \mathrm{~N} 2 \mathrm{O} 5$ & 378.2155 & + & 5 & \\
\hline Saccharine (Saccharine ${ }^{13} \mathrm{C} 6$ ) & $81-07-2$ & C7H5NO3S & 182.999 & - & 1 & \\
\hline Sucralose (Sucralose-d6) & $56038-13-2$ & $\mathrm{C} 12 \mathrm{H} 19 \mathrm{Cl} 3 \mathrm{O} 8$ & 396.0146 & - & 4 & \\
\hline \multicolumn{7}{|c|}{ INDUSTRIAL CHEMICALS } \\
\hline $\begin{array}{l}\text { 1,2-Bis-(4,4'-dinitro-2,2'-disulfonic acid) } \\
\text {-phenylethylenoxide }\end{array}$ & $128-42-7$ & $\mathrm{C} 14 \mathrm{H} 10 \mathrm{~N} 2 \mathrm{O} 10 \mathrm{~S} 2$ & 429.9771 & - & 200 & \\
\hline 4,4'-Diaminostilben-2,2'-disulfonic acid & $81-11-8$ & $\mathrm{C} 14 \mathrm{H} 14 \mathrm{~N} 2 \mathrm{O} 6 \mathrm{~S} 2$ & 370.0288 & - & 20 & \\
\hline $\mathrm{N}$-(4-Aminophenyl)-N-methyl-acetamide & $119-63-1$ & $\mathrm{C} 9 \mathrm{H} 12 \mathrm{~N} 2 \mathrm{O}$ & 164.0944 & + & 5 & \\
\hline N-Methylacetanilide & $579-10-2$ & $\mathrm{C} 9 \mathrm{H} 11 \mathrm{NO}$ & 149.0835 & + & 1 & \\
\hline \multicolumn{7}{|c|}{ CORROSION INHIBITORS } \\
\hline 1-Hydroxy-Benzotriazole & $2592-95-2$ & C6H5N3O & 135.0433 & + & 40 & Benzotriazole \\
\hline $\begin{array}{l}\text { 1-Methyl-Benzotriazole } \\
4+5 \text {-Methyl-Benzotriazole (5-Methyl- }\end{array}$ & $13351-73-0$ & $\mathrm{C} 7 \mathrm{H} 7 \mathrm{~N} 3$ & 133.0635 & + & 1 & Benzotriazole \\
\hline Benzotriazole-d6) & $136-85-6$ & $\mathrm{C} 7 \mathrm{H} 7 \mathrm{~N} 3$ & 133.0635 & + & 50 & \\
\hline 4-Hydroxy-Benzotriazole & $26725-51-9$ & $\mathrm{C} 6 \mathrm{H} 5 \mathrm{~N} 3 \mathrm{O}$ & 135.0433 & + & 40 & Benzotriazole \\
\hline Benzotriazole (Benzotrazole-d4) & $95-14-7$ & $\mathrm{C} 6 \mathrm{H} 5 \mathrm{~N} 3$ & 119.0478 & + & 25 & \\
\hline \multicolumn{7}{|c|}{ OTHERS } \\
\hline Benzophenone & $131-57-7$ & $\mathrm{C} 14 \mathrm{H} 12 \mathrm{O} 3$ & 228.0781 & + & 10 & Personal care product \\
\hline Caffeine (Caffeine-d9) & $58-08-2$ & $\mathrm{C} 8 \mathrm{H} 10 \mathrm{~N} 4 \mathrm{O} 2$ & 194.0798 & + & 50 & Tracer \\
\hline Climbazole & $38083-17-9$ & $\mathrm{C} 15 \mathrm{H} 17 \mathrm{CIN} 2 \mathrm{O} 2$ & 292.0979 & + & 50 & $\begin{array}{l}\text { Personal care product } \\
\text { Metabolite of }\end{array}$ \\
\hline Galaxolidon (Surrogate: Propiconazole-d5) & 256393-37-0 & $\mathrm{C} 18 \mathrm{H} 24 \mathrm{O} 2$ & 272.1771 & + & 10 & Galaxolide \\
\hline
\end{tabular}


In addition to the surrogate standards indicated in the table, the following surrogates were also used: N,N-diethyl-3-methylbenzamide-d7; octilinone-d17; propazine-d6; 2',2'-difluoro-2-deoxyuridine- $-{ }^{13} \mathrm{C},{ }^{15} \mathrm{~N} 2 ; \quad 5$-fluorouracil- ${ }^{15} \mathrm{~N} 2 ; \quad$ bisphenol-A-d16; ciprofloxacin-d8; erythromycin- ${ }^{13} \mathrm{C} 2 ; \quad$ irbesartan-d3; $\mathrm{N}, \mathrm{O}-$ didesmethylvenlaflaxin-d3; N-desmethylvenlaflaxin-d3; nelfinavir-d3; norfloxacin-d5; O-desmethylvenlaflaxin-d6; oxcarbazepine-d4. 
Table S2. Summary of ESI and HRMS parameters used for analysis of Beenyup AWRP samples.

\begin{tabular}{lll} 
Parameter & $\begin{array}{l}\text { positive } \\
(+\mathrm{eV})\end{array}$ & $\begin{array}{l}\text { negative } \\
(-\mathrm{eV})\end{array}$ \\
\hline Source Voltage $(\mathrm{kV})$ & 4 & 3 \\
Capillary Temp $\left({ }^{\circ} \mathrm{C}\right)$ & 350 & 350 \\
Sheath Gas Flow (Arb) & 40 & 40 \\
Aux Gas Flow (Arb) & 10 & 10 \\
Sweep Gas Flow (Arb) & 0 & 0 \\
Gas Heater Temp & 50 & 50 \\
S-Lense-RF (V) & 50 & 50 \\
Quadrupole scan range $(m / z)$ & $100-1000$ & $100-1000$ \\
FTMS Full AGC Target & $5 \mathrm{E} 5$ & $5 \mathrm{E} 5$ \\
FTMS MS2 AGC Target & $5 \mathrm{E} 5$ & $5 \mathrm{E} 5$ \\
lon Trap and FT Micro Scans & 1 & 1 \\
Dynamic exclusion & 8 & 8 \\
for MS2 (sec) & & 250 \\
FTMS Full Max lon Time (ms) & 250 & 250 \\
FTMS MSn Max lon Time (ms) & 250 & 1 \\
MS2 Isolation window $(m / z)$ & 1 & \\
Arb: arbitrary units; $m s:$ milli seconds & &
\end{tabular}


Table S3. Summary of the enviMass1.2 parameters adopted for quantitative screening of target substances.

\begin{tabular}{|l|c|}
\hline \multicolumn{1}{|c|}{ EnviMass Parameter } & Value \\
\hline \multicolumn{2}{|c|}{ blank subtraction } \\
\hline $\mathrm{m} / \mathrm{z}$ tolerance & $10 \mathrm{ppm}$ \\
\hline RT window & $0.4 \mathrm{~min}$ \\
\hline Safety factor & 4 \\
\hline \multicolumn{2}{|c|}{ before recalibration } \\
\hline $\begin{array}{l}\mathrm{m} / \mathrm{z} \text { tolerance for internal } \\
\text { standard }\end{array}$ & $10 \mathrm{ppm}$ \\
\hline $\mathrm{RT}$ tolerance & $1 \mathrm{~min}$ \\
\hline \multicolumn{2}{|c|}{ after recalibration } \\
\hline$m / z$ tolerance for targets & $4 \mathrm{ppm}$ \\
\hline $\mathrm{RT}$ tolerance & $1 \mathrm{~min}$ \\
\hline $\begin{array}{l}\text { RT tolerance for } \\
\text { isotopic/adduct peak }\end{array}$ & $0.3 \mathrm{~min}$ \\
\hline Isotopic abundance tolerance & $50 \%$ \\
\hline Intensity cut-off & 5000 \\
\hline
\end{tabular}

$R T$ : retention time; $\mathrm{m} / \mathrm{z}$ : mass-to-charge ration

Table S4. Summary of the Formulator parameters adopted for quantitative screening of target substances.

\begin{tabular}{|c|c|}
\hline Formulator Parameter & Value \\
\hline Average by scan & 3 \\
\hline$m / z$ tolerance & $\pm 5 \mathrm{ppm}$ \\
\hline RT tolerance & $1 \mathrm{~min}$ \\
\hline MassChromatogram S/N & 0.85 \\
\hline Signal threshold S/N & 10 \\
\hline RT window & $0.5-20 \mathrm{~min}$ \\
\hline Average by scan & 3 \\
\hline$m / z$ tolerance & $\pm 5 \mathrm{ppm}$ \\
\hline
\end{tabular}

$R T$ : retention time; S/N: signal-to-noise ratio; $\mathrm{m} / \mathrm{z}$ : mass-to-charge ration 
Table S5. Summary of the recovery percentages from a $100 \mathrm{ng}$ spike. Recoveries are presented only for the 13 compounds which were subsequently detected in the post RO and post UV water samples.

\begin{tabular}{|c|c|c|c|c|}
\hline Chemical & $\begin{array}{c}\text { RO water + } \\
\text { 100 ng spike } \\
\text { (ng in vial) }\end{array}$ & $\begin{array}{c}\text { RO water } \\
\text { Blank } \\
\text { (ng in vial) }\end{array}$ & $\begin{array}{c}\text { Relative } \\
\text { recovery \% }\end{array}$ & $\begin{array}{c}\text { Ultrapure } \\
\text { water } \\
\text { blank }\end{array}$ \\
\hline $\begin{array}{c}\text { 5-Methyl } \\
\text { benzotriazole* }\end{array}$ & 1700 & 1300 & $\mathrm{~N} / \mathrm{A}$ & $<\mathrm{LOD}$ \\
\hline Benzotriazole* & 2200 & 1600 & $\mathrm{~N} / \mathrm{A}$ & $<\mathrm{LOD}$ \\
\hline Galaxolidone & 170 & 40 & $130 \%$ & $<\mathrm{LOD}$ \\
\hline Lamotrigine & 100 & 5 & $95 \%$ & $<\mathrm{LOD}$ \\
\hline Metholachor & 125 & 30 & $95 \%$ & $<\mathrm{LOD}$ \\
\hline Metformin & 325 & 220 & $105 \%$ & $<\mathrm{LOD}$ \\
\hline Propiconazol & 115 & 30 & $85 \%$ & $<\mathrm{LOD}$ \\
\hline Prosulfocarb & 110 & 25 & $85 \%$ & $<\mathrm{LOD}$ \\
\hline Tramadol & 110 & 1 & $109 \%$ & $<\mathrm{LOD}$ \\
\hline Acesulfam & 170 & 55 & $115 \%$ & $<\mathrm{LOD}$ \\
\hline Saccharin & 115 & 14 & $101 \%$ & $<\mathrm{LOD}$ \\
\hline Sucralose & 110 & 15 & $95 \%$ & $<\mathrm{LOD}$ \\
\hline
\end{tabular}

*outside linearity range 
Table S6: Main physical-chemical properties of the chemicals that were detected in post RO and post UV water at Beenyup AWRP. Chemicals have been ordered by molecular weight.

\begin{tabular}{|c|c|c|c|c|c|c|c|}
\hline Chemical & $\begin{array}{l}\text { Molecular } \\
\text { structure }\end{array}$ & $\begin{array}{l}\text { Chemical typel } \\
\text { classification }\end{array}$ & $\begin{array}{l}\text { Molecular } \\
\text { weight } \\
\text { (Da) }\end{array}$ & pKa & $\begin{array}{l}\text { Log } \\
\text { Kow }\end{array}$ & $\begin{array}{l}\text { ChemSpider } \\
\text { ID }\end{array}$ & $\begin{array}{l}\text { Estimated } \\
\text { RO } \\
\text { rejection }\end{array}$ \\
\hline Benzotriazole & & $\begin{array}{l}\text { Various household } \\
\text { and industrial uses/ } \\
\text { corrosion inhibitor }\end{array}$ & 119 & 8.2 & 1.23 & 6950 & Very poor $^{1-3}$ \\
\hline Metformin & & $\begin{array}{l}\text { Pharmaceutical/ } \\
\text { diabetes treatment }\end{array}$ & 129 & 12.4 & -1.43 & 3449 & Very poor $r^{1,2}$ \\
\hline $\begin{array}{l}4+5 \text { methyl } \\
\text { benzotriazole }\end{array}$ & & $\begin{array}{l}\text { Various household } \\
\text { and industrial uses/ } \\
\text { corrosion inhibitor }\end{array}$ & 133 & 8.7 & 1.89 & 109219 & Very poor ${ }^{1-3}$ \\
\hline $\begin{array}{l}\text { Triethyl } \\
\text { phosphate }\end{array}$ & & Flame retardant & 182 & 19 & 0.80 & 6287 & Very poor ${ }^{1,2}$ \\
\hline Saccharin & & $\begin{array}{l}\text { Food additive/ } \\
\text { artificial sweetener }\end{array}$ & 183 & 2.32 & 0.91 & 4959 & Very poor $r^{1,2}$ \\
\hline Acesulfame-K & & $\begin{array}{c}\text { Food additive/ } \\
\text { artificial sweetener }\end{array}$ & 201 & 3.2 & -1.33 & 55940 & Very poor ${ }^{1,2}$ \\
\hline
\end{tabular}




\begin{tabular}{|c|c|c|c|c|c|c|c|}
\hline Chemical & $\begin{array}{l}\text { Molecular } \\
\text { structure }\end{array}$ & $\begin{array}{l}\text { Chemical type/ } \\
\text { classification }\end{array}$ & $\begin{array}{l}\text { Molecular } \\
\text { weight } \\
\text { (Da) }\end{array}$ & pKa & $\begin{array}{l}\text { Log } \\
\text { Kow }\end{array}$ & $\begin{array}{c}\text { ChemSpider } \\
\text { ID }\end{array}$ & $\begin{array}{c}\text { Estimated } \\
\text { RO } \\
\text { rejection }\end{array}$ \\
\hline Prosulfocarb & & $\begin{array}{l}\text { Pesticide/ } \\
\text { herbicide }\end{array}$ & 251 & $\cdots$ & 4.65 & 55867 & Good $^{1,2}$ \\
\hline Lamotrigine & & $\begin{array}{c}\text { Pharmaceutical/ } \\
\text { antiepileptic }\end{array}$ & 255 & 5.7 & -0.19 & 3741 & $\begin{array}{l}\text { Moderate to } \\
\text { good }^{1,2}\end{array}$ \\
\hline Tramadol & & $\begin{array}{c}\text { Pharmaceutical/ } \\
\text { analgesic }\end{array}$ & 263 & 9.41 & 2.51 & 5322 & Good $^{1,2}$ \\
\hline Galaxolidone & & $\begin{array}{l}\text { Polycyclic musk } \\
\text { fragrance/ } \\
\text { personal care } \\
\text { product }\end{array}$ & 272 & $\ldots$ & 5.50 & 28290252 & Good $^{2}$ \\
\hline Metolachlor & & $\begin{array}{l}\text { Pesticide/ } \\
\text { herbicide }\end{array}$ & 283 & & 3.00 & 4025 & $\begin{array}{l}\text { Moderate to } \\
\text { good }^{1,2}\end{array}$ \\
\hline Propiconazole & & $\begin{array}{l}\text { Biocide/ } \\
\text { fungicide }\end{array}$ & 341 & $\sim 1$ & 3.88 & 39402 & $\begin{array}{l}\text { Moderate to } \\
\text { good }^{1,2}\end{array}$ \\
\hline
\end{tabular}




\begin{tabular}{|c|c|c|c|c|c|c|c|}
\hline Chemical & $\begin{array}{l}\text { Molecular } \\
\text { structure }\end{array}$ & $\begin{array}{l}\text { Chemical type/ } \\
\text { classification }\end{array}$ & $\begin{array}{l}\text { Molecular } \\
\text { weight } \\
\text { (Da) }\end{array}$ & pKa & $\begin{array}{l}\text { Log } \\
\text { Kow }\end{array}$ & $\begin{array}{c}\text { ChemSpider } \\
\text { ID }\end{array}$ & $\begin{array}{c}\text { Estimated } \\
\text { RO } \\
\text { rejection }\end{array}$ \\
\hline Sucralose & & $\begin{array}{c}\text { Food additive/ } \\
\text { artificial sweetener }\end{array}$ & 396 & 11.8 & 0.68 & 64561 & Good $^{1,2}$ \\
\hline
\end{tabular}

1. C. Bellona, J. E. Drewes, P. Xu and G. Amy, Water Res., 2004, 38, 2795-2809.

2. J. E. Drewes, D. Sedlak, S. Snyder and E. Dickenson, Development of Indicators and Surrogate for Chemical Contaminant Removal during Wastewater Treatment and Reclamation, WateReuse Foundation, Alexandria, VA, 2008.

3. C. Loi, F. Busetti, K. L. Linge and C. Joll, J. Chrom. A, 2013, 1299, 48-57. 


\section{References}

1. Water Forever: Towards Climate Resilience. ISBN 174043521 4, Water Corporation of Western Australia, Perth, Western Australia, 2009.

2. A. J. Watkinson, E. J. Murby and S. D. Costanzo, Water Res., 2007, 41, 4164-4176.

3. J. E. Drewes, M. Reinhard and P. Fox, Water Res., 2003, 37, 3612-3621.

4. J. E. Drewes, D. Sedlak, S. Snyder and E. Dickenson, Development of Indicators and Surrogates for Chemical Contaminant Removal during Wastewater Treatment and Reclamation WRF03-014, WateReuse Foundation, Alexandria, 2008.

5. P. Van Buynder, R. Lugg, C. Rodriguez, M. Bromley, J. Filmer, P. Blair, M. Handyside, S. Higginson, N. Turner, O. Lord, P. Taylor, K. Courtney, C. Newby, A. Heitz, K. Linge, J. Blythe, F. Busetti and S. Toze, Premier's Collaborative Research Program (2005-2008). Characterising Treated Wastewater For Drinking Purposes Following Reverse Osmosis Treatment. Technical Report, Department of Health, Western Australia, 2009.

6. J. E. Drewes and P. Fox, Water Environ. Res., 2000, 72, 353-362.

7. C. Bellona, J. E. Drewes, P. Xu and G. Amy, Water Res., 2004, 38, 2795-2809.

8. B. B. Levine, K. Madireddi, V. Lazarova, M. K. Stenstrom and M. Suffet, Water Sci. Technol., 1999, 40, 293-301.

9. M. Reinhard, N. L. Goodman, P. L. McCarty and D. G. Argo, J. Am. Water Work Assoc., 1986, 78, 163-174.

10. K. L. Linge, P. Blair, F. Busetti, C. Rodriguez and A. Heitz, J. Water Supply Res. T., 2012, 61, 494-505.

11. J. Y. M. Tang, F. Busetti, J. W. A. Charrois and B. I. Escher, Water Res., 2014, 60, 289-299.

12. C. Loi, F. Busetti, K. L. Linge and C. Joll, J. Chrom. A, 2013, 1299, 48-57.

13. S. Allard, J. W. A. Charrois, C. A. Joll and A. Heitz, J. Chrom. A, 2012, 1238, 15-21.

14. S. Kern, K. Fenner, H. P. Singer, R. P. Schwarzenbach and J. Hollender, Environ. Sci. Technol., 2009, 43, 7039-7046.

15. M. Loos, M. Ruff and H. Singer, enviMass version 1.0 target screening software, Eawag: Swiss Federal Institute of Aquatic Science and Technology, Dübendorf, Switzerland, 2011.

16. S. Weiss and T. Reemtsma, Anal. Chem., 2005, 77, 7415-7420.

17. D. S. Hart, L. C. Davis, L. E. Erickson and T. M. Callender, Microchem. J., 2004, 77, 9-17.

18. S. Weiss, J. Jakons and T. Reemtsma, Environ. Sci. Technol., 2006, 40, 7193-7199.

19. T. Reemtsma, U. Miehe, U. Duennbier and M. Jekel, Water Res., 2010, 44, 596-604.

20. X. Wu, N. Chou, D. Lupher and L. Davis, Proceedings of the 1998 Conference on Hazardous Waste Research, Snowbird, Utah, 1998.

21. D. Fernandes, G. Dimastrogiovanni, M. Blázquez and C. Porte, Environ. Pollut., 2013, 174, 214-221.

22. J. L. Reiner and K. Kannan, Chemosphere, 2006, 62, 867-873.

23. K. Bester, J. Environ. Monitor., 2005, 7, 43-51.

24. G. G. Rimkus and M. Wolf, Chemosphere, 1996, 33, 2033-2043.

25. K. Kannan, J. L. Reiner, S. H. Yun, E. E. Perrotta, L. Tao, B. Johnson-Restrepo and B. D. Rodan, Chemosphere, 2005, 61, 693-700.

26. A. Kortenkamp, O. Martin, M. Faust, R. Evans, R. McKinlay, F. Orton and E. Rosivatz, State of the art assessment of endocrine disrupters. Final Report, European Commission, 2011. 
27. H. Ruedel, W. Boehmer and C. Schroeter-Kermani, J. Environ. Monitor., 2006, 8, 812-823.

28. X.-W. Wang, J.-F. Liu and Y.-G. Yin, J. Chrom. A, 2011, 1218, 6705-6711.

29. I. van der Veen and J. de Boer, Chemosphere, 2012, 88, 1119-1153.

30. H. Takigami, G. Suzuki, Y. Hirai and S.-i. Sakai, Chemosphere, 2009, 76, 270-277.

31. L. Barbosa, M. Berk and M. Vorster, Journal of Clinical Psychiatry, 2003, 64, 403407.

32. M. O. Rojas-Corrales, E. Berrocoso, J. Gibert-Rahola and J. A. Mico, Journal of Psychopharmacology, 2004, 18, 404-411.

33. WHO Model List of Essential Medicines, 18th edn., World Health Organisation, Geneva, Switzerland, 2013.

34. Therapeutic Goods Administration, http://www.tga.gov.au/, Australian Government, Department of Health, Canberra, 2014.

35. M. Scheurer, A. Michel, H. J. Brauch, W. Ruck and F. Sacher, Water Res., 2012, 46, 4790-4802.

36. I. J. Buerge, H. R. Buser, M. Kahle, M. D. Muller and T. Poiger, Environ. Sci. Technol., 2009, 43, 4381-4385.

37. I. Ferrer and E. M. Thurman, J. Chrom. A, 2010, 1217, 4127-4134.

38. R. Loos, B. M. Gawlik, K. Boettcher, G. Locoro, S. Contini and G. Bidoglio, J. Chrom. A, 2009, 1216, 1126-1131.

39. N. Lubick, Environ. Sci. Technol., 2008, 42, 3125.

40. N. Lubick, Environ. Sci. Technol., 2009, 43, 4220-4220.

41. R. N. Mead, J. B. Morgan, G. B. Avery Jr, R. J. Kieber, A. M. Kirk, S. A. Skrabal and J. D. Willey, Mar. Chem., 2009, 116, 13-17.

42. M. Scheurer, H.-J. Brauch and F. Lange, Anal. Bioanal. Chem., 2009, 394, 15851594.

43. M. Scheurer, F. R. Storck, H. J. Brauch and F. T. Lange, Water Res., 2010, 44, 35733584.

44. F. T. Lange, M. Scheurer and H.-J. Brauch, Anal. Bioanal. Chem., 2012, 403, 25032518.

45. M. Scheurer, M. Godejohann, A. Wick, O. Happel, T. A. Ternes, H.-J. Brauch, W. K. L. Ruck and F. T. Lange, Environ. Sci. Pollut. R., 2012, 19, 1107-1118.

46. J. L. Gerlock, W. Tang, M. A. Dearth and T. J. Korniski, Polym. Degrad. Stabil., 1995, 48, 121-130.

47. M. A. Dearth, T. J. Korniski and J. L. Gerlock, Polym. Degrad. Stabil., 1995, 48, 111120.

48. M. Scheurer, B. Schmutz, O. Happel, H. J. Brauch, R. Wülser and F. R. Storck, Sci. Total Environ., 2014, 481, 425-432.

49. M. M. Huber, T. A. Ternes and U. Von Gunten, Environmental Science and Technology, 2004, 38, 5177-5186.

50. T. Haddad, E. Baginska and K. Kümmerer, Water Res., 2014.

51. S. D. Richardson and T. A. Ternes, Anal. Chem., 2014, 86, 2813-2848.

52. T. Kosjek, S. Perko, D. Žigon and E. Heath, J. Chromatogr., A, 2013, 1290, 62-72.

53. Australian Guidelines for Water Recycling: Managing Health and Environmental Risks. Augmentation of Drinking Water Supplies, Environment Protection and Heritage Council, National Health and Medical Research Council, Natural Resource Management Ministerial Counci, Canberra, 2008.

54. Australian Drinking Water Guidelines 6, National Health and Medical Research Council, Natural Resource Management Ministerial Council, Canberra, 2011. 
55. Memorandum of Understanding between the Department of Health and Water Corporation for Recycled Water, Water Corporation of Western Australia, Government of Western Australia Department of Health, Perth, Western Australia, 2010.

56. Martindale, Martindale, The Complete Drug Reference, 36th edition, Pharmaceutical Press, London, UK, 2009

57. Conclusion regarding the peer review of the pesticide risk assessment of the active substance prosulfocarb, European Food Safety Authority, Parma, Italy, 2007.

58. F. D. L. Leusch, S. J. Khan, S. Laingam, E. Prochazka, S. Froscio, T. Trinh, H. F. Chapman and A. Humpage, Water Res., 2014, 49, 300-315.

59. B. I. Escher, M. Allinson, R. Altenburger, P. A. Bain, P. Balaguer, W. Busch, J. Crago, N. D. Denslow, E. Dopp, K. Hilscherova, A. R. Humpage, A. Kumar, M. Grimaldi, B. S. Jayasinghe, B. Jarosova, A. Jia, S. Makarov, K. A. Maruya, A. Medvedev, A. C. Mehinto, J. E. Mendez, A. Poulsen, E. Prochazka, J. Richard, A. Schifferli, D. Schlenk, S. Scholz, F. Shiraishi, S. Snyder, G. Su, J. Y. M. Tang, B. V. D. Burg, S. C. V. D. Linden, I. Werner, S. D. Westerheide, C. K. C. Wong, M. Yang, B. H. Y. Yeung, X. Zhang and F. D. L. Leusch, Environmental Science and Technology, 2014, 48, 1940-1956.

60. M. Macova, S. Toze, L. Hodgers, J. F. Mueller, M. Bartkow and B. I. Escher, Water Res., 2011, 45, 4238-4247.

61. J. E. Drewes, J. D. C. Hemming, J. J. Schauer and W. C. Sonzogni, Removal of Endocrine Disrupting Compounds in Water Reclamation Processes, Water Environment Research Fundation, 2006. 